\title{
Formation of organometallic hydroxo and oxo complexes by oxidation of transition metal hydrides in the presence of water. X-Ray structures of $\left[\mathrm{CpMo}(\mathrm{OH})\left(\mathrm{PMe}_{3}\right)_{3}\right]\left[\mathrm{BF}_{4}\right]$ and $\left[\mathrm{CpMo}(\mathrm{O})\left(\mathrm{PMe}_{3}\right)_{2}\right]\left[\mathrm{BF}_{4}\right]$
}

\author{
James C. Fettinger, ${ }^{a}$ Heinz-Bernhard Kraatz, ${ }^{a \dagger}$ Rinaldo Poli ${ }^{* b}$ and E. Alessandra Quadrelli ${ }^{a}$
}

${ }^{a}$ Department of Chemistry and Biochemistry, University of Maryland, College Park, Maryland 20742

${ }^{b}$ Laboratoire de Synthèse et d'Electrosynthèse Organométalliques, Faculté des Sciences "Gabriel”, Université de Bourgogne, 6 Boulevard Gabriel, 21000 Dijon, France,

Correspondence to: Prof. Rinaldo Poli

Laboratoire de Synthèse et d'Electrosynthèse Organometalliques

Faculté des Sciences "Gabriel"

6, Boulevard Gabriel

21100 Dijon (France)

tel: $+33-03.80 .39 .68 .81$

fax: +33-03.80.39.60.98

E-mail: poli@u-bourgogne.fr 


\section{Abstract}

The decomposition of complex $\left[\mathrm{CpMoH}\left(\mathrm{PMe}_{3}\right)_{3}\right]^{+}, \mathbf{1}^{+}$, in wet, weakly coordinating solvents (THF and acetone) leads to the formation of the Mo(III) hydroxo compound $\left[\mathrm{CpMo}(\mathrm{OH})\left(\mathrm{PMe}_{3}\right)_{3}\right]\left[\mathrm{BF}_{4}\right]$, 2, and the $\mathrm{Mo}(\mathrm{IV})$ oxo compound $\left[\mathrm{CpMo}(\mathrm{O})\left(\mathrm{PMe}_{3}\right)_{2}\right]\left[\mathrm{BF}_{4}\right], \mathbf{3}$. Both of these have been characterized by X-ray crystallography. The formation of these products is rationalized by a mechanism which involves water coordination followed by multiple steps of tandem oxidation and deprotonation reactions. The proposed $\left[\mathrm{CpMoH}\left(\mathrm{PMe}_{3}\right)_{3}\left(\mathrm{H}_{2} \mathrm{O}\right)\right]^{2+}$ intermediate is observed by NMR spectroscopy. EPR monitoring of the oxidation of $\mathbf{1}$ with ferrocenium shows also the formation of a species characterized by a binomial triplet resonance and interpreted as the neutral Mo(III)-oxo complex $\mathrm{CpMo}(\mathrm{O})\left(\mathrm{PMe}_{3}\right)_{2}, 4$. The proposed mechanism is in harmony with the previously investigated mechanism of decomposition of $\mathbf{1}^{+}$in dry solvents and with the coupled proton and electron transfer processes that relate aqua, hydroxo, and oxo species in the chemistry of Mo enzymes. Computational studies at the DFT level were carried out on a model system where the $\mathrm{PMe}_{3}$ ligand was replaced by $\mathrm{PH}_{3}$. Their results are consistent with the proposed mechanism.

\section{Introduction}

The oxidation of transition metal hydride complexes and the reactivity of the resulting oxidation products has recently been the subject of intensive and detailed investigations. ${ }^{1-36}$ Oxidation of typical 18-electron neutral hydride complexes, $\mathrm{M}-\mathrm{H}$, dramatically increases the acidity of the hydride ligand in the resulting 17 -electron products $[\mathrm{M}-\mathrm{H}]^{+}$, resulting in its rapid decomposition by deprotonation (see Scheme 1).16 The cationic hydride can be deprotonated either by an external base or by the unoxidized starting compound, resulting in different oxidation stoichiometries [equations (1)-(3)]. In particular, deprotonation by an external base [path $a$, equation (1)] leads to the consumption of 2 oxidizing equivalents per $\mathrm{M}-\mathrm{H}$ molecule, while deprotonation by $\mathrm{M}-\mathrm{H}$ [path $b$, equations (2) and (3)] leads to the consumption of 1 oxidizing equivalent per $\mathrm{M}-\mathrm{H}$ molecule. The difference between equations (2) and (3) is related to the susceptibility of the protonated $\left[\mathrm{MH}_{2}\right]^{+}$product to lose $\mathrm{H}_{2}$ in favor of coordination of solvent $(\mathrm{S})$.

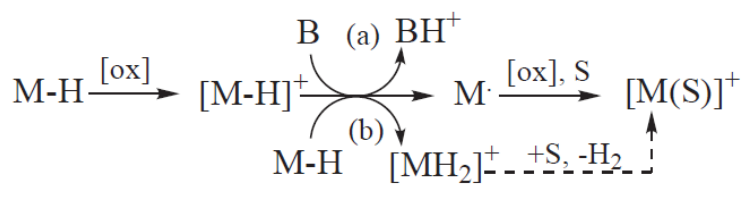

\section{Scheme 1}


$\mathrm{M}-\mathrm{H}+\mathrm{S}+\mathrm{B} \rightarrow[\mathrm{M}(\mathrm{S})]^{+}+\mathrm{BH}^{+}-2 \mathrm{e}^{-}$

$2 \mathrm{M}-\mathrm{H}+\mathrm{S} \rightarrow[\mathrm{M}(\mathrm{S})]^{+}+\left[\mathrm{MH}_{2}\right]^{+}-2 \mathrm{e}^{-}$

$2 \mathrm{M}-\mathrm{H}+2 \mathrm{~S} \rightarrow 2[\mathrm{M}(\mathrm{S})]^{+}+\mathrm{H}_{2}-2 \mathrm{e}^{-}$

In some cases, the oxidation stoichiometry for the same hydride material depends upon whether the complex is oxidized chemically or electrochemically. ${ }^{16,26}$ This phenomenon has been attributed to the presence of adventitious water as an external base in the electrochemical cell. We have recently studied in detail the influence of water on the oxidation and protonation of compounds $\mathrm{CpMoH}(\mathrm{CO})_{2} \mathrm{~L}\left(\mathrm{~L}=\mathrm{PMe}_{3}, \mathrm{PPh}_{3}\right)$ and described the general phenomenon of the action of an external base as a "proton shuttle" ${ }^{37}$ In essence, when B is a stronger base than M$\mathrm{H}$, equation (1) is thermodynamically favored over equations (2) and (3), but if the less favored protonation of $\mathrm{M}-\mathrm{H}$ is followed by irreversible $\mathrm{H}_{2}$ loss, then the $\mathrm{BH}^{+}$product delivers its proton to unoxidized $\mathrm{M}-\mathrm{H}$, changing the stoichiometry to that of equation (3).

However, deprotonation is not the only decomposition pathway available to oxidized hydride complexes. When good donor and/or sterically encumbering ligands are coordinated to the metal center in the precursor hydride complex $\mathrm{M}-\mathrm{H}$, the acidity (either kinetic or thermodynamic) of $[\mathrm{M}-\mathrm{H}]^{+}$is not sufficiently high, allowing further oxidation with concomitant solvent (S) coordination, to yield $[\mathrm{M}-\mathrm{H}(\mathrm{S})]^{2+}$ as an intermediate of a decomposition mechanism by disproportionation (Scheme 2). ${ }^{30}$ This dicationic hydride can then be deprotonated, leading to the same possibilities of oxidation stoichiometries encountered for the alternative decomposition mechanism of Scheme 1.

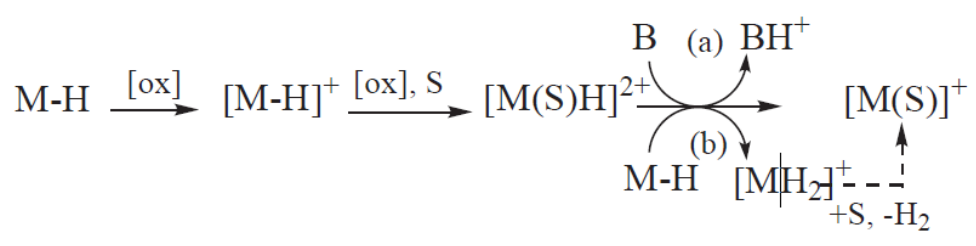

\section{Scheme 2}

While, in most cases, the $[\mathrm{M}-\mathrm{H}]^{1}$ and $[\mathrm{M}(\mathrm{S}) \mathrm{H}]^{2+}$ intermediates are too unstable to be spectroscopically observed, the oxidation of the electron-rich and sterically crowded $\mathrm{CpMoH}\left(\mathrm{PMe}_{3}\right)_{3}$ complex, 1, has allowed the formation and spectroscopic observation of the relatively stable one-electron oxidation product, $\mathbf{1}^{+}$, and the isolation and single crystal X-ray analysis of $\left[\mathrm{CpMoH}\left(\mathrm{PMe}_{3}\right)_{3}(\mathrm{MeCN})\right]^{2+}{ }^{38}$ The steric bulk and donor power of the ancillary 
ligands in this system are sufficiently great to slow down the deprotonation process of both $\mathbf{1}^{+}$ and $[\mathbf{1}(\mathrm{MeCN})]^{2+}$ by either $\mathbf{1}$ or $\mathrm{NEt}_{3}$. In this contribution, we examine the intervention of water as a coordinative molecule ( $\mathrm{S}$ in Scheme 2) during the oxidation of compound 1 . Since free water is not sufficiently basic to engage in proton transfer reactivity for this system (i.e. as B in Schemes 1 and 2), new reactivity pathways are made possible by the presence of acidic protons on the coordinated water ligand. An unprecedented paramagnetic organometallic hydroxo derivative of $\mathrm{Mo}(\mathrm{III})$, its conjugate base, and a previously reported organometallic oxo derivative of $\mathrm{Mo}(\mathrm{IV})$ are identified as the products of this process. The geometry and energies of model compounds for the Mo(III) and Mo(IV) complexes have been calculated through geometry optimizations and have been used to draw the energetic profile of the transformations. Part of this work has previously been communicated. ${ }^{39}$

\section{Experimental}

\section{General}

All operations were carried out under an atmosphere of dinitrogen using standard glove-box and Schlenk-line techniques. Solvents were dehydrated by standard methods (THF from $\mathrm{Na} / \mathrm{K} /$ benzophenone, heptane from $\mathrm{Na}$ and acetone from $\mathrm{MgSO}_{4}$ ), deoxygenated, and distilled directly from the dehydrating agent under dinitrogen prior to use. The amount of residual water in the solvents was assessed by titration with a coulomatic Karl-Fischer titrimeter (Fisher Scientific). Complex $\mathrm{CpMoCl}\left(\mathrm{PMe}_{3}\right)_{3}$ was prepared as previously described. ${ }^{40}$

\section{Spectroscopic analyses}

Samples for ${ }^{1} \mathrm{H}$ and ${ }^{31} \mathrm{P}$ NMR in thin-walled $5 \mathrm{~mm}$ glass tubes were measured on a Bruker WP200 spectrometer. The ${ }^{1} \mathrm{H}$ NMR spectra were calibrated against the residual proton signal of the deuterated solvents. The ${ }^{31} \mathrm{P}$ NMR were calibrated against $85 \% \mathrm{H}_{3} \mathrm{PO}_{4}$ in a capillary tube which was placed in a different $5 \mathrm{~mm}$ glass tube, containing the same deuterated solvent used for the measurement. All NMR spectra are collected in Table 1. EPR measurements were carried out at the X-band microwave frequency on a Bruker ER 200 D spectrometer upgraded to ESP 300, equipped with a cylindrical ER/4103 TM 110 cavity. 
Table 1. NMR data

\begin{tabular}{|c|c|c|c|}
\hline Complex & Solvent & ${ }^{1} \mathrm{H}$ NMR $(\delta)$ & ${ }^{31} \mathrm{P}\left\{{ }^{1} \mathrm{H}\right\} \operatorname{NMR}(\delta)$ \\
\hline$\left[\mathrm{CpMoO}\left(\mathrm{PMe}_{3}\right)_{2}\right]^{+}$ & $\mathrm{CD}_{3} \mathrm{CN}$ & $\begin{array}{l}5.53(\mathrm{~s}, 5 \mathrm{H}, \mathrm{Cp}), 1.63(\mathrm{~d}, \\
\left.18 \mathrm{H}, J_{\mathrm{PH}}=9.6 \mathrm{~Hz}, \mathrm{PMe}_{3}\right)\end{array}$ & $13.3(\mathrm{~s})^{a}$ \\
\hline$\left[\mathrm{CpMoH}\left(\mathrm{PMe}_{3}\right)_{3}\left(\mathrm{H}_{2} \mathrm{O}\right)\right]^{2+c}$ & $\mathrm{CD}_{3} \mathrm{COCD}_{3}$ & $\begin{array}{l}5.26(\mathrm{~m}, 5 \mathrm{H}, \mathrm{Cp}), 1.59(\mathrm{~d}, \\
\left.27 \mathrm{H}, J_{\mathrm{HP}}=8.8 \mathrm{~Hz}, \mathrm{PMe}_{3}\right)\end{array}$ & $\begin{array}{l}10.6\left(\mathrm{t}, 1 \mathrm{P}, J_{\mathrm{PP}}=25.9 \mathrm{~Hz}\right)^{b} \\
2.8\left(\mathrm{~d}, 2 \mathrm{P}, J_{\mathrm{PP}}=24.3 \mathrm{~Hz}\right)^{b}\end{array}$ \\
\hline$\left[\mathrm{CpMoH}\left(\mathrm{PMe}_{3}\right)_{3}\left(\mathrm{H}_{2} \mathrm{O}\right)\right]^{2+c}$ & $\mathrm{CD}_{3} \mathrm{CN}$ & $5.09(\mathrm{~s}, 5 \mathrm{H}, \mathrm{Cp})^{d}$ & $\begin{array}{l}10.7\left(\mathrm{t}, 1 \mathrm{P}, J_{\mathrm{PP}}=25.1 \mathrm{~Hz}\right)^{e} \\
2.8\left(\mathrm{~d}, 2 \mathrm{P}, J_{\mathrm{PP}}=24.3 \mathrm{~Hz}\right)^{e}\end{array}$ \\
\hline$\left[\mathrm{CpMoH}\left(\mathrm{PMe}_{3}\right)_{3}\left(\mathrm{CD}_{3} \mathrm{COCD}_{3}\right)\right]^{2+}$ & $\mathrm{CD}_{3} \mathrm{COCD}_{3}$ & $\begin{array}{l}5.26(\mathrm{~m}, 5 \mathrm{H}, \mathrm{Cp}), 1.67(\mathrm{~d}, \\
\left.27 \mathrm{H}, J_{\mathrm{HP}}=5.6 \mathrm{~Hz}, \mathrm{PMe}_{3}\right)\end{array}$ & $\begin{array}{l}10.4\left(\mathrm{t}, 1 \mathrm{P}, J_{\mathrm{PP}}=22.7 \mathrm{~Hz}\right) \\
4.8\left(\mathrm{~d}, 2 \mathrm{P}, J_{\mathrm{PP}}=24.3 \mathrm{~Hz}\right)\end{array}$ \\
\hline$\left[\mathrm{CpMoH}\left(\mathrm{PMe}_{3}\right)_{3}\left(\mathrm{CD}_{3} \mathrm{COCD}_{3}\right)\right]^{2+}$ & $\mathrm{CD}_{3} \mathrm{CN}$ & $5.06(\mathrm{~s}, 5 \mathrm{H}, \mathrm{Cp})^{d}$ & \\
\hline
\end{tabular}

${ }^{a} \delta 13.2$ in $\mathrm{CD}_{3} \mathrm{COCD}_{3}$; the ${ }^{1} \mathrm{H}$ NMR of $\left[\mathrm{CpMoO}\left(\mathrm{PMe}_{3}\right)_{2}\right]^{+}$has been previously reported. ${ }^{41 b}$ Splits further into a doublet $\left(J_{\mathrm{PH}}=12 \mathrm{~Hz}\right)$ in the ${ }^{31} \mathrm{P}\left\{\right.$ selective- $\left.{ }^{1} \mathrm{H}\right\}$ NMR. ${ }^{c}$ The hydride and water resonances are not visible in the ${ }^{1} \mathrm{H}$ NMR. ${ }^{d}$ The $\mathrm{PMe}_{3}$ resonance could not be identified because of extensive overlap with the other reaction products (see Experimental section). ${ }^{e}$ Splits further into a doublet $\left(J_{\mathrm{PH}}=14 \mathrm{~Hz}\right)$ in the ${ }^{31} \mathrm{P}\left\{\right.$ selective- $\left.{ }^{1} \mathrm{H}\right\}$ NMR.

\section{Oxidation of 1 by $\mathrm{Fc}^{+} \mathrm{PF}_{6}^{-}$in $\mathrm{CD}_{3} \mathrm{CN}$ in presence of water}

The $\mathrm{CD}_{3} \mathrm{CN}$ solution $(0.753 \mathrm{~mL})$ resulting from the addition of a solution $(0.2 \mathrm{~mL})$ of $\mathrm{FcPF}_{6}$ (18.2 $\mathrm{mg}, 55 \mathrm{mmol})$ to a solution $(553 \mathrm{~mL})$ containing $1(56 \mathrm{mmol})$ and $\mathrm{H}_{2} \mathrm{O}(3 \mathrm{~mL}, 160 \mathrm{mmol})$ was monitored over time and compared to the analogous reaction performed without the addition of water. ${ }^{38}$ The ${ }^{1} \mathrm{H}$ and ${ }^{31} \mathrm{P}$ NMR spectra confirmed the previously reported formation of $\left[\mathrm{CpMoH}\left(\mathrm{CD}_{3} \mathrm{CN}\right)\left(\mathrm{PMe}_{3}\right)_{3}\right]^{2+}, \quad\left[\mathrm{CpMoH}_{2}\left(\mathrm{PMe}_{3}\right)_{3}\right]^{+}$and $\left[\mathrm{CpMo}\left(\mathrm{CD}_{3} \mathrm{CN}\right)\left(\mathrm{PMe}_{3}\right)_{3}\right]^{1} .^{38} \mathrm{In}$ addition, however, the spectra also revealed $\mathrm{Cp}$ resonances of two additional diamagnetic products whose formation does not occur under dry conditions. These were attributed to $\left[\mathrm{CpMoO}\left(\mathrm{PMe}_{3}\right)_{2}\right]^{+}$(ca. 15\% of all diamagnetic products by integration of the $\mathrm{Cp}$ resonances), and $\left[\mathrm{CpMoH}\left(\mathrm{PMe}_{3}\right)_{3}\left(\mathrm{H}_{2} \mathrm{O}\right)\right]^{2+}($ ca. 20\%).

\section{Decomposition of $\mathbf{1}^{+}$in $\mathbf{T H F}$}

(a) Isolation of $\left[\mathrm{CpMo}\left(\mathrm{PMe}_{3}\right)_{3}(\mathrm{OH})\right]\left[\mathrm{BF}_{4}\right], 2$, and $\left[\mathrm{CpMoO}\left(\mathrm{PMe}_{3}\right)_{2}\right]\left[\mathrm{BF}_{4}\right], 3$. Complex $\mathbf{1}^{+}$was generated in situ according to the literature: $:^{38,40}$ to a stirred solution of $\mathrm{CpMoCl}\left(\mathrm{PMe}_{3}\right)_{3}(149 \mathrm{mg}, 0.351 \mathrm{mmol})$ in THF $(10 \mathrm{~mL})$ was added via microsyringe a $1 \mathrm{M}$ solution of $\mathrm{LiBHEt}_{3}(351 \mathrm{~mL}, 0.351 \mathrm{mmol})$. After $30 \mathrm{~min}$, the reaction mixture was evaporated to dryness and extracted with $\mathrm{n}$-heptane $(2 \times 10 \mathrm{~mL})$, yielding a spectroscopically pure solution of $\mathrm{CpMoH}\left(\mathrm{PMe}_{3}\right)_{3}$. After filtration and evaporation to dryness, the residue was dissolved in THF and cooled to $278{ }^{\circ} \mathrm{C}$. Solid $\mathrm{AgBF}_{4}(68 \mathrm{mg}, 0.350 \mathrm{mmol})$ was added, resulting in the immediate formation of a dark brown precipitate. An aliquot of this reaction mixture was transferred into an EPR tube via cannula and frozen in liquid nitrogen until the introduction into the EPR probe, which was preset at $278^{\circ} \mathrm{C}$. The resulting EPR spectrum (doublet of quartets $[g=2.017 ; a(\mathrm{P})=28.5 \mathrm{G} ; a(\mathrm{H})=13 \mathrm{G}])$ confirmed the formation of complex $\mathbf{1}^{1}$, by comparison with the previously reported spectrum. ${ }^{38}$ 
The reaction mixture was allowed to warm to room temperature, filtered and evaporated to dryness under reduced pressure. This solid was extracted with acetone $(3 \times 10 \mathrm{~mL})$ and the resulting orange solution was filtered, reduced in volume to about $10 \mathrm{~mL}$, and the product was precipitated out by the addition of heptane $(20 \mathrm{~mL})$. Recrystallization of the dark solid from acetone-heptane led to the deposition of three types of crystals: red prisms, yellow blocks and yellow needles, which were all used for single crystal X-ray analyses. The yellow blocks and yellow needles correspond to $\left[\mathrm{CpMo}\left(\mathrm{PMe}_{3}\right)_{3}(\mathrm{OH})\right]\left[\mathrm{BF}_{4}\right], 2$, and to $\left[\mathrm{CpMo}\left(\mathrm{PMe}_{3}\right)_{3}(\mathrm{OH})_{1-\mathrm{x}} \mathrm{Cl}_{\mathrm{x}}\right]-$ $\left[\mathrm{BF}_{4}\right]$, respectively, whereas the red prisms correspond to $\left[\mathrm{CpMoO}\left(\mathrm{PMe}_{3}\right)_{2}\right]\left[\mathrm{BF}_{4}\right], 3$. A few red crystals were separated by hand-picking and investigated by NMR spectroscopy. The ${ }^{1} \mathrm{H}$ NMR spectrum in $\mathrm{CD}_{3} \mathrm{COCD}_{3}$ is identical with that previously reported for compound $3{ }^{4}$

(b) Spectroscopic study of the reaction mixture. A reaction identical to that described in the previous section was carried out from 1 ( $0.86 \mathrm{mmol})$ and $\mathrm{AgBF}_{4}(164 \mathrm{mg}, 0.84 \mathrm{mmol})$. After filtration and evaporation to dryness, the brown solid was washed with $\mathrm{Et}_{2} \mathrm{O}$ and dried under vacuum. Yield $332 \mathrm{mg}$. This solid was used for NMR and EPR investigations. EPR $\left(\mathrm{CD}_{3} \mathrm{COCD}_{3},-50{ }^{\circ} \mathrm{C}\right): \mathrm{dq}\left(g=2.032, a_{\mathrm{d}(\mathrm{H})}=14.1 \mathrm{G} ; a_{\mathrm{q}(\mathrm{P})}=28.8 \mathrm{G}, a_{\mathrm{Mo}}=29 \mathrm{G}\right)$. This spectrum is attributed to complex $\mathbf{1}^{1}$ ( $c f$. EPR spectrum in THF). ${ }^{38}$ The ${ }^{1} \mathrm{H}$ NMR spectrum $\left(\mathrm{CD}_{3} \mathrm{COCD}_{3}\right.$, $\delta$ ) showed four different products in an approximate relative ratio of $10: 60: 15: 15$, as follows. $\left[\mathrm{CpMoO}\left(\mathrm{PMe}_{3}\right)_{2}\right]^{+}$(relative intensity 10), ${ }^{41}\left[\mathrm{CpMoH}_{2}\left(\mathrm{PMe}_{3}\right)_{3}\right]^{+}$(relative intensity 60) $:^{41}$ $\left[\mathrm{CpMoH}\left(\mathrm{PMe}_{3}\right)_{3}\left(\mathrm{CD}_{3} \mathrm{COCD}_{3}\right)\right]^{2+}$ (relative intensity 15$),\left[\mathrm{CpMoH}\left(\mathrm{PMe}_{3}\right)_{3}\left(\mathrm{H}_{2} \mathrm{O}\right)\right]^{2+}$ (relative intensity 15). The $\mathrm{CD}_{3} \mathrm{COCD}_{3}$ solution was evaporated to dryness and redissolved in $\mathrm{CD}_{3} \mathrm{CN}$. The ${ }^{1} \mathrm{H}$ NMR spectrum showed five $\mathrm{Cp}$ resonances, whose relative intensities changed with time. The initial relative intensities and assignments are $23\left(\left[\mathrm{CpMoO}\left(\mathrm{PMe}_{3}\right)_{2}\right]^{1}\right): 55(\delta 4.80$, overlap of $\left[\mathrm{CpMoH}_{2}\left(\mathrm{PMe}_{3}\right)_{3}\right]^{+}$and $\left.\left[\mathrm{CpMo}\left(\mathrm{CD}_{3} \mathrm{CN}\right)\left(\mathrm{PMe}_{3}\right)_{3}\right]^{+}\right)^{38}: 7\left(\delta 5.31,\left[\mathrm{CpMoH}\left(\mathrm{PMe}_{3}\right)_{3}{ }^{-}\right.\right.$ $\left.\left.\left(\mathrm{CD}_{3} \mathrm{CN}\right)\right]^{2+}\right): 7\left(\left[\mathrm{CpMoH}\left(\mathrm{PMe}_{3}\right)_{3}\left(\mathrm{CD}_{3} \mathrm{COCD}_{3}\right)\right]^{2+}\right): 8\left(\left[\mathrm{CpMoH}\left(\mathrm{PMe}_{3}\right)_{3}\left(\mathrm{H}_{2} \mathrm{O}\right)\right]^{2+}\right)$. Over $24 \mathrm{~h}$, there is no significant change in the relative intensities of the $\left[\mathrm{CpMoO}\left(\mathrm{PMe}_{3}\right)_{2}\right]^{+}$, $\left[\mathrm{CpMoH}_{2}\left(\mathrm{PMe}_{3}\right)_{3}\right]^{+}, \quad\left[\mathrm{CpMo}\left(\mathrm{CD}_{3} \mathrm{CN}\right)\left(\mathrm{PMe}_{3}\right)_{3}\right]^{+}$and $\left[\mathrm{CpMoH}\left(\mathrm{PMe}_{3}\right)_{3}\left(\mathrm{H}_{2} \mathrm{O}\right)\right]^{2+}$ resonances, while the $\left[\mathrm{CpMoH}\left(\mathrm{PMe}_{3}\right)_{3}\left(\mathrm{CD}_{3} \mathrm{COCD}_{3}\right)\right]^{2+}$ resonance disappeared and that of $[\mathrm{CpMoH}-$ $\left.\left(\mathrm{PMe}_{3}\right)_{3}\left(\mathrm{CD}_{3} \mathrm{CN}\right)\right]^{2+}$ correspondingly increased.

\section{NMR and EPR monitoring of the decomposition of $1^{+}$in wet $\mathrm{CD}_{3} \mathrm{COCD}_{3}$. Formation of CpMoO(PMe3)2, 4}

To a $\mathrm{CD}_{3} \mathrm{COCD}_{3}$ solution $(0.5 \mathrm{~mL})$ of $\mathrm{CpMoH}\left(\mathrm{PMe}_{3}\right)_{3}(17 \mu \mathrm{mol}$, generated in situ as above $)$ was added water $(1 \mathrm{~mL}, 56 \mathrm{mmol})$ and $\mathrm{AgBPh}_{4}(4.3 \mathrm{mg}, 10 \mu \mathrm{mol}, \mathrm{Mo}: \mathrm{Ag}=1: 0.6)$. The ${ }^{1} \mathrm{H}$ NMR monitoring showed a slow reaction that eventually consumed all of the starting hydride. 
After $24 \mathrm{~h}$, an aliquot of the solution was investigated by EPR spectroscopy: binomial triplet with Mo satellites, $g=2.000, a_{\mathrm{P}}=20 \mathrm{G}, a_{\mathrm{Mo}}=30 \mathrm{G}$. This resonance is assigned to $\mathrm{CpMoO}\left(\mathrm{PMe}_{3}\right)_{2}, 4$. At the same time, the ${ }^{31} \mathrm{P}$ NMR spectrum revealed a broad $\left(\mathrm{w}_{1 / 2}=360 \mathrm{~Hz}\right)$ resonance at $\delta-36$ and a single organometallic diamagnetic product $(\delta 7.9)$, identified as $\left[\mathrm{CpMoH}_{2}\left(\mathrm{PMe}_{3}\right)_{3}\right]^{+}$by comparison with an authentic sample. ${ }^{38,41}$

An analogous experiment was carried out with a $\mathrm{CD}_{3} \mathrm{COCD}_{3}$ solution $(1.0 \mathrm{~mL})$ of $\mathrm{CpMoH}\left(\mathrm{PMe}_{3}\right)_{3}(100 \mathrm{mmol}$, generated in situ as above), containing $5 \mu \mathrm{L}(0.25 \mathrm{mmol})$ of water. In a separate Schlenk, $\mathrm{Ag}^{+} \mathrm{BF}_{4}^{-}(65 \mathrm{mg}, 0.333 \mathrm{mmol})$ was dissolved in $\mathrm{CD}_{3} \mathrm{COCD}_{3}(200 \mu \mathrm{L})$. A first aliquot ( $66 \mu \mathrm{L}, 0.11 \mathrm{mmol}$, ca. 1 equiv.) was added to the hydride solution, generating the EPR spectrum assigned to 4 (see previous section). A second aliquot of silver solution (50 $\mu \mathrm{L}, 83 \mathrm{mmol}$ ) was added to the residual solution (Mo :Ag = ca. $1: 2$ ). The resonances of complex $\left[\mathrm{CpMoO}\left(\mathrm{PMe}_{3}\right)_{2}\right]^{+}$were present in the ${ }^{1} \mathrm{H}$ NMR spectrum, while a subsequent EPR investigation showed no residual EPR activity.

\section{Protonation of 1 in the presence of $\mathrm{PMe} 3$}

Upon addition of $\mathrm{HBF}_{4} \cdot \mathrm{Et}_{2} \mathrm{O}(10 \mu \mathrm{L}, 70 \mathrm{mmol})$ to a $\mathrm{CD}_{3} \mathrm{COCD}_{3}$ solution $(0.5 \mathrm{~mL})$ of 1 (70 $\mu \mathrm{mol})$ and $\mathrm{PMe}_{3}(10 \mu \mathrm{mol})$, no changes in the ${ }^{1} \mathrm{H}$ and ${ }^{31} \mathrm{P}$ NMR resonances of the trimethylphosphine were detected, while the resonances of $\mathbf{1}$ were replaced by those of $[\mathbf{1}-\mathrm{H}]^{+}$.

\section{Protonation of 1 in the presence of $\mathrm{H}_{2} \mathrm{O}$}

Upon addition of $\mathrm{HBF}_{4} \cdot \mathrm{Et}_{2} \mathrm{O}(10 \mu \mathrm{L}, 70 \mathrm{mmol})$ to a $\mathrm{CD}_{3} \mathrm{COCD}_{3}$ solution $(0.6 \mathrm{~mL})$ of $\mathbf{1}$ (79 $\mu \mathrm{mol})$ and $\mathrm{H}_{2} \mathrm{O}(2 \mathrm{~mL}, 110 \mu \mathrm{mol})$, no major change in the ${ }^{1} \mathrm{H}$ resonance of the water peak was detected $(\delta 2.2)$, while the resonances of $\mathbf{1}$ were replaced by those of $[\mathbf{1}-\mathrm{H}]^{+}$.

\section{X-Ray crystallography}

(a) $\left[\mathrm{CpMo}(\mathrm{OH})\left(\mathrm{PMe}_{3}\right)_{3}\right]\left[\mathrm{BF}_{4}\right]$. Data collection and reduction and structure solution were routine. The structure was refined with an initial Flack parameter refining to 0.87(10) indicating that the structure needed to be inverted. Following inversion and further refinement, one of the three $\mathrm{PMe}_{3}$ groups was found to be disordered with major : minor contributors of $0.631: 0.369$. The hydroxide hydrogen was initially located in the difference Fourier map at a distance of 0.88 A from the $\mathrm{O}$ atom and a Mo-O-H angle of $140^{\circ}$, but free refinement led to instability. Thus, it was eventually refined with DFIX (restrained O-H distance and free Mo-O-H angle). Crystal data and refinement parameters are collected in Table 2, while selected bond distances and angles are listed in Table 3. 
Table 2. Crystal data for all compounds ${ }^{a}$

\begin{tabular}{|c|c|c|c|}
\hline Compound & 2 & $0.79(2) \cdot 0.21\left[\mathrm{CpMoCl}\left(\mathrm{PMe}_{3}\right)_{3}\right]\left[\mathrm{BF}_{4}\right]$ & 3 \\
\hline Formula & $\mathrm{C}_{14} \mathrm{H}_{33} \mathrm{BF}_{4} \mathrm{MoOP}_{3}$ & $\mathrm{C}_{28} \mathrm{H}_{65.58} \mathrm{~B}_{2} \mathrm{Cl}_{0.42} \mathrm{~F}_{8} \mathrm{Mo}_{2} \mathrm{O}_{1.58} \mathrm{P}_{6}$ & $\mathrm{C}_{11} \mathrm{H}_{23} \mathrm{BF}_{4} \mathrm{MoOP}_{2}$ \\
\hline $\mathrm{M}_{\mathrm{w}}$ & 493.06 & 993.78 & 415.98 \\
\hline Space group & Pna $2_{1}$ & $P 2{ }_{1} 2_{1} 2_{1}$ & Ama 2 \\
\hline$a / \AA$ & $20.525(5)$ & $8.7140(9)$ & $17.29(2)$ \\
\hline$b / \AA$ & $13.380(4)$ & $13.300(4)$ & $15.201(2)$ \\
\hline$c / \AA ̊$ & $7.9740(7)$ & $37.939(6)$ & $6.6459(6)$ \\
\hline $\mathrm{V} / \AA^{3}$ & $2189.9(9)$ & 4397(2) & $1747(2)$ \\
\hline Reflections collected, unique & 3712,3712 & 3488,3488 & 969,692 \\
\hline$R_{\text {int }}$ & - & - & 0.0336 \\
\hline $\begin{array}{l}\mu(\text { Mo-Ka }) / \mathrm{mm}^{-1} \\
R \text { indices }[I>2 \sigma(D]\end{array}$ & 0.851 & 0.872 & 0.963 \\
\hline $\begin{array}{l}R \text { indices }[I>2 \sigma(I)] \\
R 1^{b}\end{array}$ & 0.0267 & 0.0509 & 0.0391 \\
\hline$w R 2^{c}$ & 0.0567 & 0.1139 & 0.0715 \\
\hline$R$ indices (all data) & & & \\
\hline$R 1$ & 0.0353 & 0.0807 & 0.0782 \\
\hline$w R 2$ & 0.0604 & 0.1292 & 0.0801 \\
\hline
\end{tabular}

Table 3. Selected bond lengths $(\AA)$ and angles $\left(^{\circ}\right)$ for $\left[\mathrm{CpMo}(\mathrm{OH})\left(\mathrm{PMe}_{3}\right)_{3}\right]\left[\mathrm{BF}_{4}\right](2)$ and comparison with B3LYP-optimized $\left[\mathrm{CpMo}(\mathrm{OH})\left(\mathrm{PH}_{3}\right)_{3}\right]^{+a}$

\begin{tabular}{llllll}
\hline & X-ray & B3LYP & & X-ray & B3LYP \\
\hline Mo-CNT & $1.980(2)$ & 2.054 & $\mathrm{O}(1)-\mathrm{Mo}(1)-\mathrm{CNT}$ & $112.40(13)$ & 121.35 \\
$\mathrm{Mo}(1)-\mathrm{C}(1)$ & $2.302(4)$ & 2.025 & $\mathrm{P}(1)-\mathrm{Mo}(1)-\mathrm{CNT}$ & $108.52(10)$ & 112.22 \\
$\mathrm{Mo}(1)-\mathrm{C}(2)$ & $2.241(5)$ & 2.302 & $\mathrm{P}(2)-\mathrm{Mo}(1)-\mathrm{CNT}$ & $110.63(10)$ & 110.31 \\
$\mathrm{Mo}(1)-\mathrm{C}(3)$ & $2.271(4)$ & 2.474 & $\mathrm{P}(3)-\mathrm{Mo}(1)-\mathrm{CNT}$ & $110.81(10)$ & 114.38 \\
$\mathrm{Mo}(1)-\mathrm{C}(4)$ & $2.348(4)$ & & $\mathrm{P}(1)-\mathrm{Mo}(1)-\mathrm{P}(2)$ & $94.22(5)$ & 85.97 \\
$\mathrm{Mo}(1)-\mathrm{C}(5)$ & $2.369(4)$ & & $\mathrm{P}(1)-\mathrm{Mo}(1)-\mathrm{P}(3)$ & $93.21(4)$ & 85.20 \\
$\mathrm{Mo}(1)-\mathrm{P}(1)$ & $2.4533(12)$ & 2.572 & $\mathrm{P}(2)-\mathrm{Mo}(1)-\mathrm{P}(3)$ & $132.83(4)$ & 136.40 \\
$\mathrm{Mo}(1)-\mathrm{P}(2)$ & $2.4989(12)$ & 2.632 & $\mathrm{P}(1)-\mathrm{Mo}(1)-\mathrm{O}(1)$ & $139.07(10)$ & 123.70 \\
$\mathrm{Mo}(1)-\mathrm{P}(3)$ & $2.4749(11)$ & 2.557 & $\mathrm{P}(2)-\mathrm{Mo}(1)-\mathrm{O}(1)$ & $71.03(8)$ & 68.64 \\
$\mathrm{Mo}(1)-\mathrm{O}(1)$ & $2.080(3)$ & 2.050 & $\mathrm{P}(3)-\mathrm{Mo}(1)-\mathrm{O}(1)$ & $73.15(8)$ & 81.40 \\
$\mathrm{O}(1)-\mathrm{H}(1 \mathrm{~A})$ & $0.831(10)$ & 0.979 & $\mathrm{Mo}(1)-\mathrm{O}(1)-\mathrm{H}(1 \mathrm{~A})$ & $133(4)$ & 126.60 \\
& & & $\mathrm{CNT}-\mathrm{Mo}-\mathrm{O}-\mathrm{H}$ & $-20(5)$ & 83.00 \\
\hline
\end{tabular}

${ }^{a} \mathrm{CNT}=$ centroid of cyclopentadienyl ring.

(b) $\left[\mathrm{CpMo}(\mathrm{OH})_{0.79} \mathrm{Cl}_{0.21}\left(\mathrm{PMe}_{3}\right)_{3}\right]\left[\mathrm{BF}_{4}\right]$. Routine structure solution revealed two independent molecules in the asymmetric unit. During the refinement, it became apparent that one of the two molecules had disorder in the hydroxo position. Further analysis revealed that this position was composed of two different ligands, $\mathrm{OH}$ and $\mathrm{Cl}$. The ratio was determined to be $\mathrm{OH}: \mathrm{Cl}=0.58: 0.42$ by refinement of the X-ray data. The overlap on this site required the use of restraints. The Mo-O-H moiety was imposed to be identical with that in the other independent molecule. This allowed for both the hydroxyl oxygen and chlorine atoms to refine to acceptable positions. Crystal data and refinement parameters are collected in Table 2, while selected bond distances and angles are listed in Table 4. 
Table 4. Selected bond lengths $(\AA)$ and angles $\left(^{\circ}\right)$ for $\left[\mathrm{CpMo}(\mathrm{OH})_{0.79} \mathrm{Cl}_{0.21}\left(\mathrm{PMe}_{3}\right)_{3}\right]\left[\mathrm{BF}_{4}\right]$

\begin{tabular}{llll}
\hline $\mathrm{Mo}(1)-\mathrm{P}(1)$ & $2.484(4)$ & $\mathrm{Mo}(2)-\mathrm{Cl}(2)$ & $2.33(3)$ \\
$\mathrm{Mo}(1)-\mathrm{P}(2)$ & $2.481(4)$ & $\mathrm{Mo}(2)-\mathrm{P}(4)$ & $2.488(4)$ \\
$\mathrm{Mo}(1)-\mathrm{P}(3)$ & $2.456(4)$ & $\mathrm{Mo}(2)-\mathrm{P}(5)$ & $2.499(4)$ \\
$\mathrm{Mo}(1)-\mathrm{O}(1)$ & $2.078(9)$ & $\mathrm{Mo}(2)-\mathrm{P}(6)$ & $2.464(4)$ \\
$\mathrm{Mo}(1)-\mathrm{C}(1)$ & $2.25(2)$ & $\mathrm{Mo}(2)-\mathrm{O}(2)$ & $2.09(3)$ \\
$\mathrm{Mo}(1)-\mathrm{C}(2)$ & $2.25(2)$ & $\mathrm{Mo}(2)-\mathrm{C}(15)$ & $2.36(2)$ \\
$\mathrm{Mo}(1)-\mathrm{C}(3)$ & $2.31(2)$ & $\mathrm{Mo}(2)-\mathrm{C}(16)$ & $2.348(13)$ \\
$\mathrm{Mo}(1)-\mathrm{C}(4)$ & $2.36(2)$ & $\mathrm{Mo}(2)-\mathrm{C}(17)$ & $2.265(14)$ \\
$\mathrm{Mo}(1)-\mathrm{C}(5)$ & $2.31(2)$ & $\mathrm{Mo}(2)-\mathrm{C}(18)$ & $2.22(2)$ \\
$\mathrm{Mo}(1)-\mathrm{CNT}(1)$ & $1.98(2)$ & $\mathrm{Mo}(2)-\mathrm{C}(19)$ & $2.30(2)$ \\
& & $\mathrm{Mo}(2)-\mathrm{CNT}(2)$ & $1.98(2)$ \\
& & & \\
$\mathrm{P}(1)-\mathrm{Mo}(1)-\mathrm{P}(2)$ & $135.4(2)$ & $\mathrm{Cl}(2)-\mathrm{Mo}(2)-\mathrm{P}(6)$ & $138.4(9)$ \\
$\mathrm{P}(1)-\mathrm{Mo}(1)-\mathrm{P}(3)$ & $92.6(2)$ & $\mathrm{Cl}(2)-\mathrm{Mo}(2)-\mathrm{O}(2)$ & $7(3)$ \\
$\mathrm{P}(1)-\mathrm{Mo}(1)-\mathrm{O}(1)$ & $75.6(2)$ & $\mathrm{Cl}(2)-\mathrm{Mo}(2)-\mathrm{CNT}(2)$ & $113.8(11)$ \\
$\mathrm{P}(1)-\mathrm{Mo}(1)-\mathrm{CNT}(1)$ & $108.9(5)$ & $\mathrm{P}(4)-\mathrm{Mo}(2)-\mathrm{P}(5)$ & $135.70(13)$ \\
$\mathrm{P}(2)-\mathrm{Mo}(1)-\mathrm{P}(3)$ & $92.0(2)$ & $\mathrm{P}(4)-\mathrm{Mo}(2)-\mathrm{P}(6)$ & $93.7(2)$ \\
$\mathrm{P}(2)-\mathrm{Mo}(1)-\mathrm{O}(1)$ & $72.5(2)$ & $\mathrm{P}(4)-\mathrm{Mo}(2)-\mathrm{O}(2)$ & $70(2)$ \\
$\mathrm{P}(2)-\mathrm{Mo}(1)-\mathrm{CNT}(1)$ & $111.5(2)$ & $\mathrm{P}(4)-\mathrm{Mo}(2)-\mathrm{CNT}(2)$ & $108.1(5)$ \\
$\mathrm{P}(3)-\mathrm{Mo}(1)-\mathrm{O}(1)$ & $139.6(3)$ & $\mathrm{P}(5)-\mathrm{Mo}(2)-\mathrm{P}(6)$ & $91.0(2)$ \\
$\mathrm{P}(3)-\mathrm{Mo}(1)-\mathrm{CNT}(1)$ & $108.3(5)$ & $\mathrm{P}(5)-\mathrm{Mo}(2)-\mathrm{O}(2)$ & $78(2)$ \\
$\mathrm{O}(1)-\mathrm{Mo}(1)-\mathrm{CNT}(1)$ & $112.1(6)$ & $\mathrm{P}(5)-\mathrm{Mo}(2)-\mathrm{CNT}(2)$ & $112.3(5)$ \\
$\mathrm{Cl}(2)-\mathrm{Mo}(2)-\mathrm{P}(4)$ & $76.8(11)$ & $\mathrm{P}(6)-\mathrm{Mo}(2)-\mathrm{O}(2)$ & $139(2)$ \\
$\mathrm{Cl}(2)-\mathrm{Mo}(3)-\mathrm{P}(5)$ & $70.9(10)$ & $\mathrm{P}(6)-\mathrm{Mo}(2)-\mathrm{CNT}(2)$ & $107.6(5)$ \\
& & $\mathrm{O}(2)-\mathrm{Mo}(2)-\mathrm{CNT}(2)$ & $113(2)$ \\
\hline & & &
\end{tabular}

(c) $\left[\mathrm{CpMoO}\left(\mathrm{PMe}_{3}\right)_{2}\right]\left[\mathrm{BF}_{4}\right]$. Two of the $\mathrm{PMe}_{3}$ carbon atoms, $\mathrm{C} 4$ and $\mathrm{C} 5$, were found to suffer from disorder that was modeled resulting in a final ratio $\mathrm{C} 4: \mathrm{C} 4 \mathrm{~A}=\mathrm{C} 5: \mathrm{C} 5 \mathrm{~A}=$

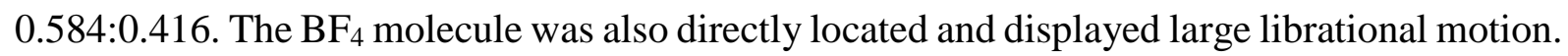
The final model included two orientations for the fluorine atoms with equal occupancy (50:50). Crystal data and refinement parameters are collected in Table 2, while selected bond distances and angles are listed in Table 5.

CCDC reference number 186/1270.

See http://www.rsc.org/suppdata/dt/1999/497/ for crystallographic files in .cif format.

Table 5. Selected bond lengths $(\AA)$ and angles $\left(^{\circ}\right)$ for $\left[\mathrm{CpMo}(\mathrm{O})\left(\mathrm{PMe}_{3}\right)_{2}\right]\left[\mathrm{BF}_{4}\right] \mathbf{3}$ and comparison with B3LYP-optimized $\left[\mathrm{CpMo}(\mathrm{OH})\left(\mathrm{PH}_{3}\right)_{2}\right]^{+a}$

\begin{tabular}{llllll}
\hline & X-ray & B3LYP & & X-ray & B3LYP \\
\hline Mo-CNT & $2.05(2)$ & 2.122 & $\mathrm{O}(1)-\mathrm{Mo}(1)-\mathrm{CNT}$ & $149.1(6)$ & 147.41 \\
$\mathrm{Mo}(1)-\mathrm{C}(1)$ & $2.20(2)$ & 2.265 & $\mathrm{P}(1)-\mathrm{Mo}(1)-\mathrm{CNT}$ & $106.9(3)$ & 107.44 \\
$\mathrm{Mo}(1)-\mathrm{C}(2)$ & $2.298(13)$ & 2.363 & $\mathrm{P}(1)-\mathrm{Mo}(1)-\mathrm{P}(1 \mathrm{~A})$ & $94.4(2)$ & 93.25 \\
$\mathrm{Mo}(1)-\mathrm{C}(3)$ & $2.521(12)$ & 2.620 & $\mathrm{P}(1)-\mathrm{Mo}(1)-\mathrm{O}(1)$ & $93.7(3)$ & 94.60 \\
$\mathrm{Mo}(1)-\mathrm{P}(1)$ & $2.445(4)$ & 2.547 & $\mathrm{P}(1)-\mathrm{Mo}(1)-\mathrm{CNT}-\mathrm{P}(1 \mathrm{~A})$ & 100.01 & 99.26 \\
$\mathrm{Mo}(1)-\mathrm{O}(1)$ & $1.674(13)$ & 1.714 & & & \\
\hline
\end{tabular}

${ }^{a} \mathrm{CNT}=$ centroid of cyclopentadienyl ring. 


\section{Theoretical calculations}

All calculations were performed using Gaussian-9442 on a SGI Origin 200 at the Université de Bourgogne and on a DEC/Alphastation 250 at the University of Maryland. The LanL2DZ set was employed to perform complete geometry optimizations with a Density Functional Theory (DFT) approach. The three-parameter form of the Becke, Lee, Yang and Parr functional (B3LYP), ${ }^{43}$ was employed. The LanL2DZ basis set includes both Dunning and Hay's D95 sets for $\mathrm{H}$ and $\mathrm{C},{ }^{44}$ and the relativistic Electron Core Potential (ECP) sets of Hay and Wadt for the heavy atoms. ${ }^{44-47}$ Electrons outside the core were all those of $\mathrm{H}, \mathrm{C}$ and $\mathrm{O}$ atoms, the $3 \mathrm{~s}$ and $3 \mathrm{p}$ electrons in $\mathrm{P}$, and the 4s, 4p, 4d and 5s electrons in Mo. The mean value of the spin of the first order electronic wavefunction, which is not an exact eigenstate of $S^{2}$ for unrestricted calculations on open-shell systems, was considered suitable to unambiguously identify the spin state. Spin contamination was carefully monitored and the energies shown in the Results section correspond to unrestricted B3LYP (UB3LYP) calculations.

\section{Results}

\section{Chemical oxidation of $\mathrm{CpMoH}\left(\mathrm{PMe}_{3}\right)_{3}$ in the presence of water}

The oxidation of $\mathbf{1}$ in dry $\mathrm{CD}_{3} \mathrm{CN}$ has been previously investigated. ${ }^{38} \mathrm{We}$ have now reexamined this process in the presence of water. The NMR monitoring shows the formation of the same products that are obtained when the solvent is dry, i.e. $\left[1\left(\mathrm{CD}_{3} \mathrm{CN}\right)\right]^{2+},[\mathbf{1}-\mathrm{H}]^{+}$and $\left[\mathrm{CpMo}\left(\mathrm{PMe}_{3}\right)_{3}\left(\mathrm{CD}_{3} \mathrm{CN}\right)\right]^{+}$. In addition, small amounts of the previously described ${ }^{41}$ complex $\left[\mathrm{CpMoO}\left(\mathrm{PMe}_{3}\right)_{2}\right]^{+}$and another species that has very similar NMR properties to those of $[\mathbf{1}(\mathrm{MeCN})]^{2+}$, were also present. The latter species could not be isolated, but its assignment to $\left[1\left(\mathrm{H}_{2} \mathrm{O}\right)\right]^{2+}$ appears most reasonable. The two species $[\mathbf{1}(\mathrm{MeCN})]^{2+}$ and $\left[1\left(\mathrm{H}_{2} \mathrm{O}\right)\right]^{2+}$ have the same pattern of ${ }^{1} \mathrm{H}$ and ${ }^{31} \mathrm{P}$ NMR resonances (one $\mathrm{Cp}$ resonance and two $\mathrm{PMe}_{3}$ resonances in a $2: 1$ ratio with similar chemical shifts and coupling constants), and both show coupling of the ${ }^{31} \mathrm{P}$ NMR resonances to a single hydride ligand upon selective decoupling $\left(J_{\mathrm{HP}}=10 \mathrm{~Hz}\right.$ for the $\mathrm{CD}_{3} \mathrm{CN}$ adduct 38 and $14 \mathrm{~Hz}$ for the $\mathrm{H}_{2} \mathrm{O}$ adduct, see Table 1). Complex $\left[1\left(\mathrm{H}_{2} \mathrm{O}\right)\right]^{2+}$ does not decompose readily in $\mathrm{CD}_{3} \mathrm{CN}(24 \mathrm{~h})$, nor does the ratio of complexes $[\mathbf{1}(\mathrm{MeCN})]^{2+}$ and $\left[1\left(\mathrm{H}_{2} \mathrm{O}\right)\right]^{2+}$ change with time. On a longer time scale, however (4 days), only the oxo and dihydrido Mo(IV) complexes are observed in solution.

The oxidation was also carried out in less coordinating solvents such as THF and acetone. The solid that could be isolated when the oxidation was carried out with one equivalent of oxidizing agent $\left(\mathrm{Ag}^{+}\right)$in THF shows, after dissolution in $\mathrm{CD}_{3} \mathrm{COCD}_{3}$, the presence of $\mathbf{1}^{+}$by 
EPR spectroscopy ${ }^{38}$ and complexes $\left[\mathrm{CpMoO}\left(\mathrm{PMe}_{3}\right)_{2}\right]^{+},[\mathbf{1}-\mathrm{H}]^{+},\left[\mathbf{1}\left(\mathrm{H}_{2} \mathrm{O}\right)\right]^{2+}$ (vide supra), and a new complex assigned as $\left[1\left(\mathrm{CD}_{3} \mathrm{COCD}_{3}\right)\right]^{2+}$ by ${ }^{1} \mathrm{H}$ and ${ }^{31} \mathrm{P}$ NMR spectroscopy. Complex $\left[1\left(\mathrm{CD}_{3} \mathrm{COCD}_{3}\right)\right]^{2+}$ shows ${ }^{1} \mathrm{H}$ and ${ }^{31} \mathrm{P}$ NMR patterns similar to those of the related $\mathrm{CD}_{3} \mathrm{CN}$ and $\mathrm{H}_{2} \mathrm{O}$ derivatives (see Table 1). The corresponding complex $[\mathbf{1}(\mathrm{THF})]^{2+}$ was previously obtained by oxidation of 1 with two equivalents of oxidant in THF, ${ }^{38}$ but its sparing solubility in THF did not permit its NMR characterization. When the isolated solid was dissolved in $\mathrm{CD}_{3} \mathrm{CN}$, the smooth transformation of $\left[1\left(\mathrm{CD}_{3} \mathrm{COCD}_{3}\right)\right]^{2+}$ to $\left[1\left(\mathrm{CD}_{3} \mathrm{CN}\right)\right]^{2+}$ could be witnessed over a few hours by NMR spectroscopy, while the resonances attributed to $\left[1\left(\mathrm{H}_{2} \mathrm{O}\right)\right]^{2+}$ remained unchanged over the same time scale.

A spectroscopic monitoring of the oxidation reaction of 1 in $\mathrm{CD}_{3} \mathrm{COCD}_{3}$ carried out in the presence of small amounts of water and with a substoichiometric amount of oxidant shows the formation of an EPR active species characterized by a triplet resonance $\left(a_{\mathrm{P}}=20 \mathrm{G}\right)$ flanked by Mo satellites $\left(a_{\mathrm{Mo}}=28 \mathrm{G}\right)$ in the EPR spectrum (see Fig. 1). This resonance disappears after the addition of an excess of oxidant. This EPR active intermediate is formulated as $\mathrm{CpMo}(\mathrm{O})\left(\mathrm{PMe}_{3}\right)_{2}, \mathbf{4}$, see Discussion. This EPR triplet must be due to an odd-electron Mo complex that contains two $\mathrm{PMe}_{3}$ ligands and no hydride ligand. Hydride ligands on Mo typically lead to large, observable coupling patterns in the EPR spectra, for instance $a_{\mathrm{H}}=12.9$ $\mathrm{G}$ in $\mathbf{1}^{+}{ }^{38}$ A simultaneous NMR investigation shows the formation of the dihydride cation [1$\mathrm{H}]^{+}$and a very broad resonance at $\delta-36$ in the ${ }^{31} \mathrm{P} \mathrm{NMR}$ spectrum. The latter is assigned to free $\mathrm{PMe}_{3}$, the broadness and shift relative to the usual ${ }^{31} \mathrm{P}$ NMR resonance ( $\delta$ ca. -60$)$ being attributed to chemical exchange with the paramagnetic compound 4 . This is confirmed by the upfield shift and sharpening of this resonance upon addition of free $\mathrm{PMe}_{3}$ to this solution. After further oxidation, the ${ }^{1} \mathrm{H}$ and ${ }^{31} \mathrm{P}$ NMR resonances of $\left[\mathrm{CpMoO}\left(\mathrm{PMe}_{3}\right)_{2}\right]^{+}$become observable, in concomitance with the disappearance of the signal of $\mathbf{4}$ from the EPR spectrum.

The recrystallization of $\mathbf{1}^{+} \mathrm{BF}_{4}^{-}$from wet acetone yields three different types of crystals. These were shown by X-ray crystallography (vide infra) to correspond to the $\mathrm{BF}_{4}^{-}$salt of the $\left[\mathrm{CpMo}(\mathrm{O})\left(\mathrm{PMe}_{3}\right)_{2}\right]^{+}$complex, compound 3, the $\mathrm{Mo}(\mathrm{III})$ hydroxo species $[\mathrm{CpMo}(\mathrm{OH})-$ $\left.\left(\mathrm{PMe}_{3}\right)_{3}\right] \mathrm{BF}_{4}, 2$, and a solid solution of the latter with $\left[\mathrm{CpMoCl}\left(\mathrm{PMe}_{3}\right)_{3}\right] \mathrm{BF}_{4}$, corresponding to the composition $\left[\mathrm{CpMo}(\mathrm{OH})_{0.79} \mathrm{Cl}_{0.21}\left(\mathrm{PMe}_{3}\right)_{3}\right] \mathrm{BF}_{4}$. The X-ray structure of a pure sample of the chloro species was reported previously. ${ }^{48}$ The presence of the chloride impurity in this material can be rationalized on the basis of the preparative chemistry, as follows. Compound $\mathbf{1}$ is very soluble in all nonpolar solvents and quite difficult to crystallize. ${ }^{40}$ For that reason, it was generated in situ by the action of $\mathrm{LiBEt}_{3} \mathrm{H}$ on $\mathrm{CpMoCl}\left(\mathrm{PMe}_{3}\right)_{3}$, this being a facile and selective reaction ${ }^{40}$ so long as care is taken to assure a complete conversion. In the present case, a residual 
chloride impurity probably contaminated the isolated product $\mathbf{1}$, and its subsequent oxidation generated, as previously established, ${ }^{40}$ the stable $\left[\mathrm{CpMoCl}\left(\mathrm{PMe}_{3}\right)_{3}\right]^{+}$cation which cocrystallized with compound 2.

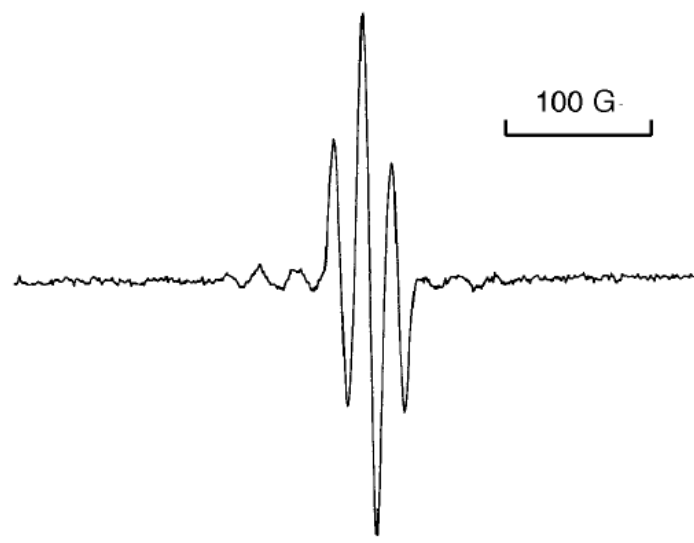

Fig. 1 Room temperature EPR spectrum of a solution of 4 in $\mathrm{CD}_{3} \mathrm{COCD}_{3}$.

Compound 2 has also been recently obtained in our laboratory by an alternative procedure, namely one-electron oxidation of the 16-electron Mo(II) hydroxo complex, $\mathrm{CpMo}(\mathrm{OH})\left(\mathrm{PMe}_{3}\right)_{2}$, in the presence of $\mathrm{PMe}_{3} .{ }^{39,49} \mathrm{~A}$ unit cell determination on single crystals confirms that the two products are identical. This compound does not lead to detectable EPR or NMR resonances. Compound $\mathbf{3}$, in turn, has previously been obtained by protonation of $\mathrm{CpMoH}(\mathrm{PMe})_{3}$ with aqueous $\mathrm{HBF}_{4}{ }^{41}$ Other similar $\mathrm{CpMo}(\mathrm{IV})$ oxo cations, i.e. $[\mathrm{CpMo}(\mathrm{O})(\text { dppe })]^{+} \mathrm{PF}_{6}^{-}$and $\left[\mathrm{CH}_{3} \mathrm{C}\left(\mathrm{CH}_{2}-\eta^{5}-\mathrm{C}_{5} \mathrm{H}_{4}\right)\left(\mathrm{CH}_{2} \mathrm{PPh}_{2}\right)_{2} \mathrm{MoO}\right]^{+},{ }^{50,51}$ have also been previously described in the literature.

\section{X-Ray structures}

The previously communicated ${ }^{39} \mathrm{X}$-ray structure of compound $\mathbf{2}$ is reported here in full. A top view of the cation is shown in Fig. 2. The geometry of the complex is the typical four-legged piano stool, the stool being the $\mathrm{Cp}$ ligand and the four legs being identified by the three $\mathrm{PMe}_{3}$ ligands and the $\mathrm{OH}$ group. The hydroxo hydrogen atom could not be freely refined and restraints were applied to the $\mathrm{O}-\mathrm{H}$ distance, but the $\mathrm{Mo}-\mathrm{O}-\mathrm{H}$ angle was refined freely and converged to 133(4)8. The Mo-CNT and Mo-P distances are the same, within experimental error, to the corresponding distances in the isostructural complex $\left[\mathrm{CpMoCl}\left(\mathrm{PMe}_{3}\right)_{3}\right]^{+} .{ }^{48}$ The shorter $\mathrm{Mo}(1)-$ $\mathrm{P}(1)$ distance relative to the $\mathrm{Mo}(1)-\mathrm{P}(2)$ and $\mathrm{Mo}(1)-\mathrm{P}(3)$ distances reflects the weaker trans influence of the $\mathrm{OH}$ group relative to $\mathrm{PMe}_{3}$. The $\mathrm{Cp}$ ligand is somewhat asymmetrically disposed on top of the metal center, the difference between the longest and the shortest Mo-C 
distance being 0.130(6) $\AA$. As is clear from Fig. 2, the two relative trans $\mathrm{PMe}_{3}$ ligands are distorted toward the $\mathrm{OH}$ ligand and away from the third $\mathrm{PMe}_{3}$ ligand. This is probably the result of the steric repulsion betweeen the bulkier $\mathrm{PMe}_{3}$ ligands. The same effect, although less pronounced, was observed for the chloro analogue. ${ }^{48}$ Compound $\mathbf{2}$ is, to the best of our knowledge, the first known compound with a terminal $\mathrm{Mo}^{\mathrm{III}}-\mathrm{OH}$ bond. The Mo-O distance, therefore, can only be compared with those found in hydroxide-bridged complexes. These comprise (averaged Mo-O distances in parentheses) $\left[\mathrm{Mo}_{2}(\mu-\mathrm{OH})_{2}\left(\mu-\mathrm{O}_{2} \mathrm{CMe}\right)(\text { edta })\right]^{-}\left(\mathrm{H}_{4} \mathrm{edta}\right.$ $=$ ethylenediaminetetraacetic acid) $[2.04(1) \AA],{ }^{52}\left[\mathrm{Mo}_{2} \mathrm{~L}_{2} \mathrm{Cl}_{2}(\mathrm{M}-\mathrm{OH})_{2}\right]^{2+}[2.13(1) \AA],{ }^{53}$ $\left[\mathrm{Mo}_{2} \mathrm{~L}_{2}\left(\mu-\mathrm{O}_{2} \mathrm{CMe}\right)(\mu-\mathrm{OH})_{2}\right]^{3+}[2.08(1) \AA],{ }^{53}$ and $\left[\mathrm{Mo}_{2} \mathrm{~L}_{2} \mathrm{Br}_{2}(\mu-\mathrm{OH})(\mu-\mathrm{Br})\right]^{2+}(\mathrm{L}=1,4,7$-triazacyclononane) [1.84(2) $\AA$ ].$^{5}$ The distance in 2 compares relatively well with some of those reported above. A compensation of different effects might be responsible for this similarity: compound $\mathbf{2}$ is electronically more saturated than the above edge-bridged bioctahedral examples (less oxygen $\pi$ bonding is allowed), and the $\mathrm{OH}$ ligand in $\mathbf{2}$ experiences a stronger trans influence from the $\mathrm{PMe}_{3}$ ligand. Both these effects should lengthen the Mo-O bond in 2. On the other hand, the terminal bonding mode in $\mathbf{2}$ will in part counter those effects. The angular distortions from the $\mathrm{Cp}$ ring are similar for all four monodentate ligands [CNT-Mo-X angles $=108.5(1), 110.7(1), 110.8(1), 112.2(2) 8$ for $\mathrm{P}(1), \mathrm{P}(2), \mathrm{P}(3)$ and $\mathrm{O}(1)$, respectively], as found for the analogous chloro derivative. ${ }^{48}$ These angular parameters have been shown to be diagnostic of the electronic configuration at the metal and the $\sigma / \pi$ bonding capabilities of the ligands. ${ }^{55,56}$

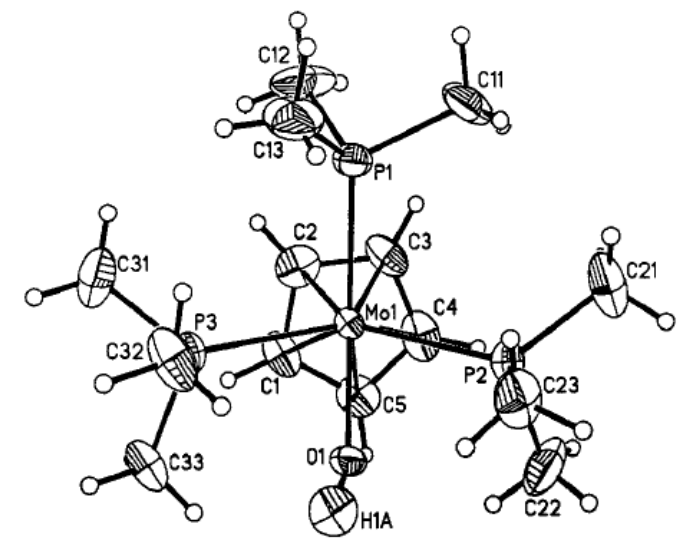

Fig. 2 A top view of the $\left[\mathrm{CpMo}(\mathrm{OH})\left(\mathrm{PMe}_{3}\right)_{3}\right]^{+}$cation in compound 2. Only the major orientation of the disordered $\mathrm{PMe}_{3}$ ligand (P1 donor atom) is shown for clarity.

A second crystal from the batch that contains crystals of $\mathbf{2}$ turned out to correspond to a solid solution of $\mathbf{2}$ and the corresponding chloro complex. The structure contains two molecules in the asymmetric unit, the first one corresponding to a fully ordered hydroxide derivative (Fig. 3 ) and the second one to a compositional disorder of the hydroxide and the chloride in a $58: 42$ 
ratio (Fig. 4). It is somewhat curious that the $\mathrm{OH} / \mathrm{Cl}$ disorder is only observed in one of the two crystallographically independent molecules. The metric parameters of both molecules compare very well with those of the crystal structure of pure 2 described above (cf. Tables 3 and 4). The closeness of all bonding and angular parameters between the two complexes rationalizes the ease with which they form a solid solution. However, the molecular packing is not quite identical for the two complexes, since the pure chloride forms monoclinic crystals (space group $P 2{ }_{1} / c$ ), whereas the pure hydroxide and the solid solution crystallize in different orthorhombic space groups (see Table 2).

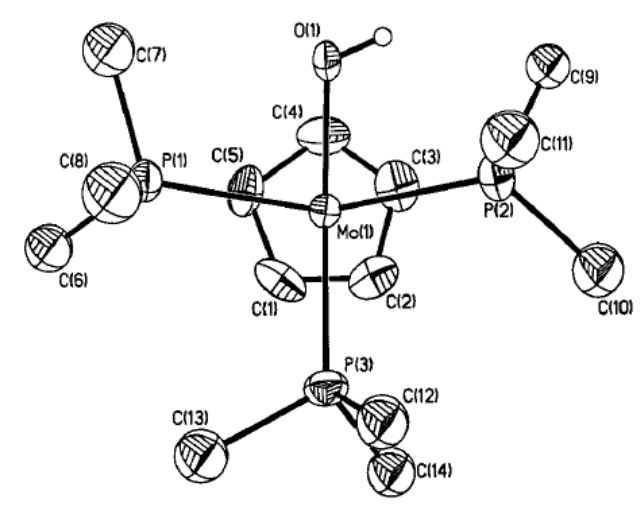

Fig. 3 A top view of the $\left[\mathrm{CpMo}(\mathrm{OH})\left(\mathrm{PMe}_{3}\right)_{3}\right]^{+}$cation in the structure of $\left[\mathrm{CpMo}(\mathrm{OH})_{0.79} \mathrm{Cl}_{0.21^{-}}\right.$ $\left.\left(\mathrm{PMe}_{3}\right)_{3}\right]^{+} \mathrm{BF}_{4}^{-}$. Ellipsoids are drawn at the $30 \%$ probability level.

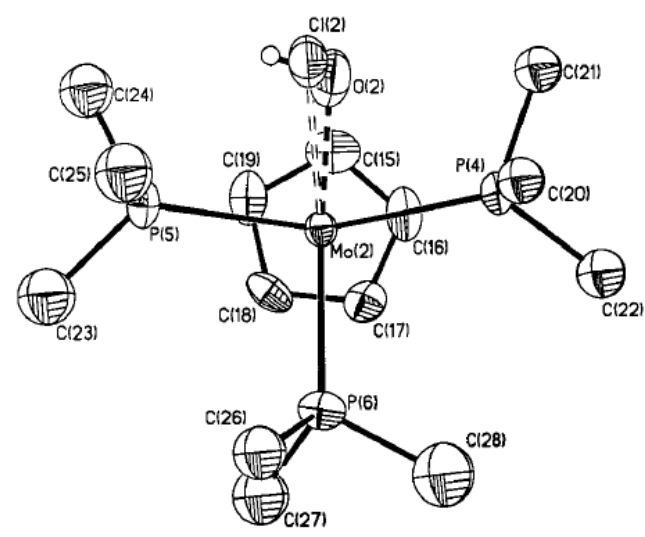

Fig. 4 A top view of the disordered $\left[\mathrm{CpMo}(\mathrm{OH})_{0.58} \mathrm{Cl}_{0.42}\left(\mathrm{PMe}_{3}\right)_{3}\right]^{+}$cation in the structure of $\left[\mathrm{CpMo}(\mathrm{OH})_{0.79} \mathrm{Cl}_{0.21}\left(\mathrm{PMe}_{3}\right)_{3}\right]^{+} \mathrm{BF}_{4}{ }^{-}$. Ellipsoids are drawn at the $30 \%$ probability level.

Compound 3 was previously reported ${ }^{41}$ but not crystallographically characterized. A view of the $\left[\mathrm{CpMo}(\mathrm{O})\left(\mathrm{PMe}_{3}\right)_{2}\right]^{+}$ion is shown in Fig. 5. The short Mo-O distance of 1.674(13) $\AA$ is an immediate indication of the multiple bonding between these two atoms. Other terminal $\mathrm{Mo}(\mathrm{IV})-\mathrm{O}$ (oxo) bonds are 1.710(3) $\AA$ for $\left[\mathrm{MeC}\left(\mathrm{CH}_{2}-\eta^{5}-\mathrm{C}_{5} \mathrm{H}_{4}\right)\left(\mathrm{CH}_{2} \mathrm{PPh}_{2}\right)_{2} \mathrm{MoO}\right]^{+},{ }^{51} 1.68(1) \AA$ for $\left[\mathrm{Mo}(\mathrm{O}) \mathrm{I}(\mathrm{dmpe})_{2}\right]^{+},{ }^{57} 1.676(7)$ and 1.801(9) $\AA$ for cis, mer $-\mathrm{MoOCl}_{2}(\mathrm{~L})_{3}\left(\mathrm{~L}=\mathrm{PMe}_{2} \mathrm{Ph}\right.$ and 
$\mathrm{PEt}_{2} \mathrm{Ph}$, respectively), 58,59 and 1.8184(8) $\AA$ in trans $-\mathrm{MoO}_{2}(\mathrm{dppe})_{2}{ }^{60}$ Some of the previously reported values might be artificially long because of what has been initially described as "bondstretch isomerism" and later recognized as a disorder-related artifact. ${ }^{61}$ The Mo-O distance found for $\mathbf{3}$, however, is close to the shortest distances ever reported, thus we strongly believe that there are no disorder problems (e.g. $\mathrm{O} / \mathrm{Cl}$ compositional disorder) in this case. The Mo-P distance is shorter than in compound $\mathbf{2}$, as expected for the smaller ionic radius associated with the higher oxidation state. The $\mathrm{Cp}$ ring is highly distorted for this compound, with the carbon atoms trans to the oxo ligand being the furthest away from the metal center. This phenomenon has also been observed for the isoelectronic $\mathrm{Cp}^{*} \mathrm{ReOCl}_{2}$ molecule. ${ }^{62}$

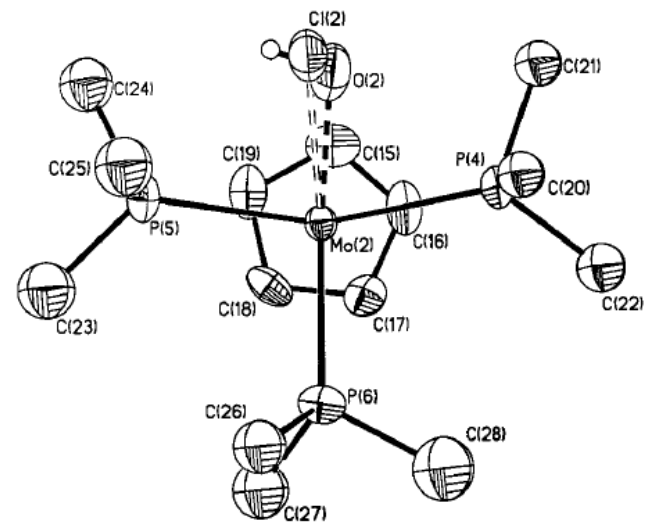

Fig. 5 A view of the $\left[\mathrm{CpMo}(\mathrm{O})\left(\mathrm{PMe}_{3}\right)_{2}\right]^{+}$ion in compound 3. Ellipsoids are drawn at the $30 \%$ probability level.

\section{Computational studies}

Geometry optimizations have been carried out on model complexes where the $\mathrm{PMe}_{3}$ ligand is replaced with $\mathrm{PH}_{3}$. The systems investigated are the singlet $\mathrm{Mo}(\mathrm{IV})$ complexes [CpMoO$\left.\left(\mathrm{PH}_{3}\right)_{2}\right]^{+}\left(C_{\mathrm{s}}\right),\left[\mathrm{CpMoH}_{2}\left(\mathrm{PH}_{3}\right)_{3}\right]^{+}\left(C_{\mathrm{s}}\right)$, and $\left[\mathrm{CpMoH}(\mathrm{OH})\left(\mathrm{PH}_{3}\right)_{3}\right]^{+}\left(C_{1}\right)$, the $\mathrm{Mo}(\mathrm{II})$ aqua complex $\left[\mathrm{CpMo}\left(\mathrm{PH}_{3}\right)_{3}\left(\mathrm{H}_{2} \mathrm{O}\right)\right]^{+}\left(C_{1}\right)$, and the $\mathrm{Mo}(\mathrm{III})$ doublet species $\left[\mathrm{CpMoH}\left(\mathrm{PH}_{3}\right)_{3}\right]^{+}\left(C_{\mathrm{s}}\right)$, $\left[\mathrm{CpMo}(\mathrm{OH})(\mathrm{PH} 3)_{3}\right]^{+}\left(C_{1}\right)$ and $\mathrm{CpMo}(\mathrm{O})\left(\mathrm{PH}_{3}\right)_{2}\left(C_{\mathrm{s}}\right)$. For the purpose of estimating reaction energies (see Discussion), optimized geometries and energies were also obtained for the redox $\mathrm{Fe}(\mathrm{II} / \mathrm{III})$ couple $\mathrm{Cp}_{2} \mathrm{Fe}^{\mathrm{n}+}(\mathrm{n}=0,1$; singlet and doublet, respectively) and for the inorganic base $\mathrm{PH}_{3}$ and its conjugated acid $\mathrm{PH}_{4}{ }^{+}$. All calculations with mirror-imposed symmetry were carried out only with eclipsed $\mathrm{Cp}$ and $\mathrm{X}$ ligands (i.e. with the unique $\mathrm{Cp}$ carbon atom eclipsed with a ligand). Calculations on both eclipsed and staggered geometries for $\left[\mathrm{CpMoO}\left(\mathrm{PH}_{3}\right)_{2}\right]^{+}$show a difference of only $0.9 \mathrm{kcal} \mathrm{mol}^{-1}(1 \mathrm{cal}=4.184 \mathrm{~J})$, and previous studies on other half-sandwich systems, namely $\mathrm{CpMoCl}_{2}\left(\mathrm{PH}_{3}\right)(\mathrm{M}=\mathrm{Cr}, \mathrm{Mo})^{63}$ and $\mathrm{CpMo}\left(\mathrm{PH}_{2}\right)\left(\mathrm{PH}_{3}\right)_{2}{ }^{49}$ have shown analogous small differences in energy between the two possible $C_{\mathrm{s}}$ conformations. All energies of relevant systems are collected in Table 6. The optimized bonding parameters for the 
$\left[\mathrm{CpMo}(\mathrm{OH})\left(\mathrm{PH}_{3}\right)_{3}\right]^{+}$and $\left[\mathrm{CpMoO}\left(\mathrm{PH}_{3}\right)_{2}\right]^{+}$species are compared with the X-ray results in Tables 3 and 5, respectively, while those of the other Mo complexes are collected in Table 7. The comparison between experimental and calculated geometries is excellent. The main differences consist in the well known overestimation of the bond distances by the DFT method, ${ }^{64}$ while the angular parameters are very similar. Other minor differences are attributable to the different steric encumbrance of the $\mathrm{PMe}_{3}$ ligand relative to the $\mathrm{PH}_{3}$ model. Views of all optimized Mo complexes are shown in Fig. 6.

Table 6 Spin state, U3BLYP total energies, and UB3LYP $S(S+1)$ for various systems

\begin{tabular}{llll}
\hline System & Spin state & Total energy/ $E_{\mathrm{h}}$ & $S(S+1)$ \\
\hline $\left.\mathrm{CpMoO}\left(\mathrm{PH}_{3}\right)_{2}\right]^{+}$ & Singlet & -352.6380 & 0 \\
{$\left[\mathrm{CpMo}(\mathrm{OH})\left(\mathrm{PH}_{3}\right)_{3}\right]^{+}$} & Doublet & -361.5012 & 0.7556 \\
$\mathrm{CpMoO}\left(\mathrm{PH}_{3}\right)_{2}$ & Doublet & -352.8176 & 0.7556 \\
$\mathrm{CpMoH}\left(\mathrm{PH}_{3}\right)_{3}{ }^{a}$ & Singlet & -286.4484 & \\
$\mathrm{CpMo}(\mathrm{OH})\left(\mathrm{PH}_{3}\right)_{3}{ }^{a}$ & Singlet & -361.6866 & \\
$\mathrm{CpMo}(\mathrm{OH})\left(\mathrm{PH}_{3}\right)_{2}{ }^{a}$ & Triplet & -353.4096 & \\
{$\left[\mathrm{CpMoH}(\mathrm{PH})_{3}\right]^{+}$} & Singlet & -286.8546 & 0 \\
{$\left[\mathrm{CpMoH}(\mathrm{OH})\left(\mathrm{PH}_{3}\right)_{3}\right]^{+}$} & Singlet & -362.0893 & 0 \\
{$\left[\mathrm{CpMo}(\mathrm{PH})_{3}\left(\mathrm{H}_{2} \mathrm{O}\right)\right]^{+}$} & Singlet & -362.0957 & 0 \\
{$\left[\mathrm{CpMo}(\mathrm{H})\left(\mathrm{PH}_{3}\right)_{3}\right]^{+}$} & Doublet & -286.2541 & 0.7560 \\
$\mathrm{PH}_{3}{ }^{a}$ & Singlet & -8.2699 & \\
{$[\mathrm{PH}]^{+}$} & Singlet & -8.5697 & 0 \\
$\mathrm{Cp}_{2} \mathrm{Fe}$ & Singlet & -510.4397 & 0 \\
{$\left[\mathrm{Cp}_{2} \mathrm{Fe}\right]^{+}$} & Doublet & -510.2030 & 0.8135 \\
\hline
\end{tabular}

${ }^{a}$ Data from ref. 49.

Table 7 B3LYP-optimized selected geometric parameters for $\mathrm{CpMoO}\left(\mathrm{PH}_{3}\right)_{2}$, $\mathrm{CpMoH}_{2}\left(\mathrm{PH}_{3}\right)_{3}{ }^{+}, \mathrm{CpMoH}(\mathrm{OH})\left(\mathrm{PH}_{3}\right)_{3}{ }^{+}, \mathrm{CpMo}\left(\mathrm{H}_{2} \mathrm{O}\right)\left(\mathrm{PH}_{3}\right)_{3}{ }^{+}$and $\left[\mathrm{CpMoH}\left(\mathrm{PH}_{3}\right)_{3}\right]^{1}{ }^{a}$

\begin{tabular}{|c|c|c|c|c|c|c|}
\hline Compound & Distance/Å & & Angle $/^{\circ}$ & & Dihedral angle $^{\circ}$ & \\
\hline \multirow{6}{*}{$\mathrm{CpMoO}\left(\mathrm{PH}_{3}\right)_{2}$} & $\mathrm{Mo}-\mathrm{CNT}^{a}$ & 2.100 & CNT-Mo-O & 157.95 & P-Mo-CNT-P & 108.53 \\
\hline & $\mathrm{Mo}-\mathrm{C}_{1}$ & 2.262 & CNT-Mo-P & 109.50 & O-Mo-CNT-P & 122.73 \\
\hline & $\mathrm{Mo}-\mathrm{C}_{2}$ & 2.372 & $\mathrm{P}-\mathrm{Mo}-\mathrm{P}$ & 99.79 & & \\
\hline & $\mathrm{Mo}-\mathrm{C}_{3}$ & 2.57 & $\mathrm{O}-\mathrm{Mo}-\mathrm{P}$ & 84.03 & & \\
\hline & Mo-P & 2.701 & & & & \\
\hline & Mo-O & 1.746 & & & & \\
\hline \multirow[t]{9}{*}[\mathrm{CpMoH}_{2}(\mathrm{PH}_{3})_{3}]{$^{+}$} & Mo-CNT & 2.030 & $\mathrm{CNT}-\mathrm{Mo}-\mathrm{H}_{e q}$ & 104.03 & & \\
\hline & Mo- $-\mathrm{H}_{\mathrm{ax}}$ & 1.691 & $\mathrm{CNT}-\mathrm{Mo}-\mathrm{H}_{a x}$ & 170.49 & & \\
\hline & $\mathrm{Mo}-\mathrm{H}_{\mathrm{eq}}$ & 1.718 & CNT-Mo-P $\mathrm{P}_{\text {trans }}$ & 141.10 & & \\
\hline & Mo-P $\mathrm{P}_{\text {trans }}$ & 2.583 & CNT-Mo-P $\mathrm{P}_{c i s}$ & 111.26 & & \\
\hline & Mo-- $\mathrm{P}_{c i s}$ & 2.583 & $\mathrm{H}_{e q}-\mathrm{Mo}-\mathrm{P}_{t}$ & 141.10 & & \\
\hline & & & $\mathrm{H}_{e q}-\mathrm{Mo}-\mathrm{P}_{c}$ & 78.01 & & \\
\hline & & & $\mathrm{H}_{e q}-\mathrm{Mo}-\mathrm{H}_{a x}$ & 66.46 & & \\
\hline & & & $\mathrm{P}_{c i s}-\mathrm{Mo}-\mathrm{P}_{c i} \mathrm{~S}$ & 134.95 & & \\
\hline & & & $\mathrm{P}_{\text {trans }}-\mathrm{Mo}-\mathrm{P}_{c i s}$ & 87.68 & & \\
\hline \multirow[t]{5}{*}[\mathrm{CpMoH}(\mathrm{OH})(\mathrm{PH}_{3})_{3}]{$^{+}$} & Mo-CNT & 2.084 & $\mathrm{CNT}-\mathrm{Mo}-\mathrm{H}$ & 173.50 & & \\
\hline & Mo-H & 1.716 & CNT-Mo-O & 106.58 & & \\
\hline & $\mathrm{Mo}-\mathrm{O}$ & 2.034 & CNT-Mo-P $\mathrm{P}_{\text {trans }}$ & 107.29 & & \\
\hline & $\mathrm{O}-\mathrm{H}$ & 0.980 & $\mathrm{CNT}-\mathrm{Mo}-\mathrm{P}_{c i s}$ & 110.57 & & \\
\hline & & & & 111.17 & & \\
\hline
\end{tabular}




\begin{tabular}{|c|c|c|c|c|c|c|}
\hline & Mo-- $\mathrm{P}_{\text {trans }}$ & 2.597 & $\mathrm{H}-\mathrm{Mo}-\mathrm{P}_{\text {trans }}$ & 66.22 & & \\
\hline & \multirow{10}{*}{ Mo-- $\mathrm{P}_{c i s}$} & 2.565 & $\mathrm{H}-\mathrm{Mo}-\mathrm{P}_{c i s}$ & 69.70 & & \\
\hline & & 2.540 & & 69.77 & & \\
\hline & & & $\mathrm{O}-\mathrm{Mo}-\mathrm{P}_{\text {trans }}$ & 145.62 & & \\
\hline & & & $\mathrm{O}-\mathrm{Mo}-\mathrm{P}_{c i s}$ & 86.25 & & \\
\hline & & & & 74.56 & & \\
\hline & & & $\mathrm{O}-\mathrm{Mo}-\mathrm{H}$ & 79.91 & & \\
\hline & & & $\mathrm{P}_{\text {trans }}-\mathrm{Mo}-\mathrm{P}_{\text {cis }}$ & 87.82 & & \\
\hline & & & & 87.43 & & \\
\hline & & & $\mathrm{P}_{c i s}-\mathrm{Mo}-\mathrm{P}_{c i s}$ & 137.48 & & \\
\hline & & & Mo-O-H & 121.02 & & \\
\hline \multirow{9}{*}[\mathrm{CpMo}(\mathrm{H}_{2}\mathrm{O})(\mathrm{PH}_{3})_{3}]{$^{+}$} & Mo-CNT & 2.044 & $\mathrm{CNT}-\mathrm{Mo}-\mathrm{O}$ & 106.96 & CNT-Mo-O-H & 85.50 \\
\hline & Mo-O & 2.294 & CNT-Mo-Ptrans & 110.14 & $\mathrm{P}_{\text {trans }}-\mathrm{Mo}-\mathrm{CNT}-\mathrm{P}_{\text {cis }}$ & 92.19 \\
\hline & $\mathrm{O}-\mathrm{H}$ & 0.975 & $\mathrm{CNT}-\mathrm{Mo}-\mathrm{P}_{c i s}$ & 122.58 & & \\
\hline & Mo-- $\mathrm{P}_{\text {trans }}$ & 2.540 & $\mathrm{O}-\mathrm{Mo}-\mathrm{P}_{\text {trans }}$ & 142.89 & & \\
\hline & Mo-- $\mathrm{P}_{c i s}$ & 2.530 & $\mathrm{O}-\mathrm{Mo}-\mathrm{P}_{c i s}$ & 79.17 & & \\
\hline & & & $\mathrm{P}_{\text {trans }}-\mathrm{Mo}-\mathrm{P}_{\text {cis }}$ & 81.07 & & \\
\hline & & & $\mathrm{P}_{c i s}-\mathrm{Mo}-\mathrm{P}_{c i s}$ & 114.70 & & \\
\hline & & & Mo-O-H & 123.83 & & \\
\hline & & & $\mathrm{H}-\mathrm{O}-\mathrm{H}$ & 111.84 & & \\
\hline \multirow[t]{5}{*}[\mathrm{CpMoH}(\mathrm{PH}_{3})_{3}]{$^{+}$} & Mo-CNT & 2.021 & CNT-Mo-H & 102.05 & $\mathrm{P}_{\text {tran }}-\mathrm{Mo}-\mathrm{CNT}-\mathrm{P}_{\text {cis }}$ & 102.83 \\
\hline & Mo-H & 1.705 & CNT-Mo-Ptrans & 115.44 & & \\
\hline & Mo-- $\mathrm{P}_{\text {trans }}$ & 2.575 & $\mathrm{CNT}-\mathrm{Mo}-\mathrm{P}_{c i s}$ & 120.96 & & \\
\hline & $\mathrm{Mo}-\mathrm{P}_{c i s}$ & 2.564 & $\mathrm{P}_{c i s}-\mathrm{Mo}-\mathrm{P}_{c i s}$ & 113.41 & & \\
\hline & & & $\mathrm{P}_{\text {trans }}-\mathrm{Mo}-\mathrm{P}_{c i s}$ & 87.17 & & \\
\hline
\end{tabular}

${ }^{a} \mathrm{CNT}=$ centroid of cyclopentadienyl ring.
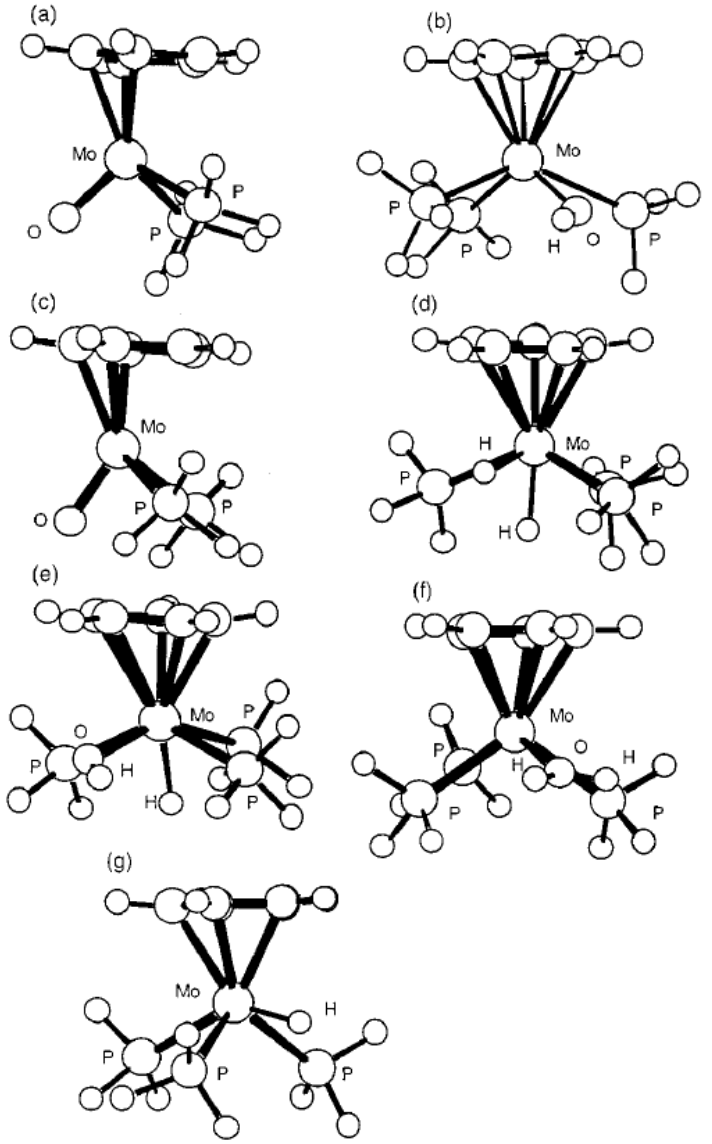

Fig. 6 Optimized geometries of (a) $\left[\mathrm{CpMoO}\left(\mathrm{PH}_{3}\right)_{2}\right]^{+}$; (b) $\left[\mathrm{CpMo}(\mathrm{OH})\left(\mathrm{PH}_{3}\right)_{3}\right]^{+}$; (c) $\mathrm{CpMo}(\mathrm{OH})$ $\left(\mathrm{PH}_{3}\right)_{2}(\mathrm{~S}=1 / 2)$; (d) $\left[\mathrm{CpMoH}_{2}\left(\mathrm{PH}_{3}\right)_{3}\right]^{+}$; (e) $\left[\mathrm{CpMoH}(\mathrm{OH})\left(\mathrm{PH}_{3}\right)_{3}\right]^{+}$; (f) $\left[\mathrm{CpMo}\left(\mathrm{PH}_{3}\right)_{3}\left(\mathrm{H}_{2} \mathrm{O}\right)\right]^{+}$; (g) $\left[\mathrm{CpMoH}\left(\mathrm{PH}_{3}\right)_{3}\right]^{+}$. 
The geometry of $\mathrm{CpMoO}\left(\mathrm{PH}_{3}\right)_{2}$ converged to a pseudotetrahedral coordination environment with one position occupied by a $\eta^{3}-\mathrm{Cp}$ ligand [Fig. 6(c)], similar to the corresponding one-electron oxidation product, $\left[\mathrm{CpMoO}\left(\mathrm{PH}_{3}\right)_{2}\right]^{+}[$Fig. 6(a)]. The shortening of all the bonds to the Mo atom (especially the Mo-P bonds) upon oxidation is perfectly consistent with the increased effective charge of the oxidized Mo center. The derivative $\left[\mathrm{CpMoH}_{2}\left(\mathrm{PH}_{3}\right)_{3}\right]^{+}$ [Fig. 6(d)] was optimized starting from a pseudo-octahedral geometry with the Cp ring and one hydride occupying the axial positions and the three phosphine ligands adopting a mer arrangement in the equatorial plane.

This geometry is indicated for the previously reported ${ }^{41}\left[\mathrm{CpMoH}_{2}\left(\mathrm{PMe}_{3}\right)_{3}\right]^{+}$complex by low-temperature ${ }^{1} \mathrm{H}$ and ${ }^{31} \mathrm{P}$ NMR studies ${ }^{38}$ and corresponds to that observed by X-ray crystallography for the isoelectronic complex $\mathrm{CpMoH}_{3}(\mathrm{PMe} 2 \mathrm{Ph})_{2}{ }^{65} \mathrm{~A}$ similar geometry is also adopted by the isoelectronic complex $\left[\left(\mathrm{C}_{6} \mathrm{H}_{5} \mathrm{Me}\right) \mathrm{WH}_{2}\left(\mathrm{PMe}_{3}\right)_{3}\right]_{2}{ }^{+}{ }^{66}$ The input geometry for $\left[\mathrm{CpMoH}(\mathrm{OH})\left(\mathrm{PH}_{3}\right)_{3}\right]^{+}$was derived from the optimized $\left[\mathrm{CpMoH}_{2}\left(\mathrm{PH}_{3}\right)_{3}\right]^{+}$geometry, by replacement of the equatorial $\mathrm{H}$ ligand with $\mathrm{OH}$. Two different optimizations were carried out, with an initial dihedral CNT-Mo-O-H angle of $45^{\circ}$ and $135^{\circ}$, respectively, leading to the same final result [Fig. 6(e)]. The equatorial placement of the $\mathrm{OH}$ ligand and the axial placement of the hydrido ligand are suggested by the identical stereochemistry of the isoelectronic $\left[\mathrm{CpMoH}\left(\mathrm{PMe}_{3}\right)_{3}(\mathrm{MeCN})\right]^{2+}{ }^{38}$ The metric parameters correspond rather closely to those of the dihydride cation, the major difference being that the axial hydride ligand is now pushed more strongly by the hydroxo ligand, thus bending toward the $\mathrm{P}_{\text {trans }}$ atom. This is an indication that the hydrogen atom has indeed hydridic character, resulting in a repulsive effect of the oxygen lone pairs. Complex $\left[\mathrm{CpMo}\left(\mathrm{PH}_{3}\right)_{3}\left(\mathrm{H}_{2} \mathrm{O}\right)\right]^{+}$was generated by adding a proton to $\mathrm{CpMo}(\mathrm{OH})\left(\mathrm{PH}_{3}\right)_{3}{ }^{49}$ in $C_{1}$ symmetry, leading, however, to a pseudo- $C_{2 \mathrm{v}}$ final geometry as shown in Fig. 6(f). In view of the fact that the metal is formally saturated in this complex, it is somewhat surprising to find a nearly planar environment at oxygen (the sum of bond angles at oxygen is $359.50^{\circ}$ ).

The geometry of optimized $\left[\mathrm{CpMoH}\left(\mathrm{PH}_{3}\right)_{3}\right]^{+}[\mathrm{Fig} .6(\mathrm{~g})]$ is very similar with that of the neutral precursor. A comparison of the bond distances and bond angles of $\mathrm{CpMoH}\left(\mathrm{PH}_{3}\right)_{3}{ }^{+}$with those previously obtained ${ }^{49}$ for $\mathrm{CpMoH}\left(\mathrm{PH}_{3}\right)_{3}$ shows that, upon oxidation, the $\mathrm{Mo}-\mathrm{Cp}$ and $\mathrm{Mo}-$ $\mathrm{H}$ bonds shorten, while the Mo-P bonds lengthen. The same effects have been noted for the $\left[\mathrm{CpWH}_{3}\left(\mathrm{H}_{2} \mathrm{PCH}_{2} \mathrm{CH}_{2} \mathrm{PH}_{2}\right)\right]^{\mathrm{n}+}(\mathrm{n}=0,1)$ pair. ${ }^{67}$ In addition, there is an overall increase in the umbrella compression of the "legs" of the four legged piano stool structure. In comparison with the $\left[\mathrm{CpMo}\left(\mathrm{PH}_{3}\right)_{3}(\mathrm{OH})\right]^{+}$and $\left[\mathrm{CpMo}\left(\mathrm{PH}_{3}\right)_{3}\left(\mathrm{H}_{2} \mathrm{O}\right)\right]^{+}$structures, the steric repulsion between two adjacent $\mathrm{PH}_{3}$ ligands results in a wider $\mathrm{P}-\mathrm{Mo}-\mathrm{P}$ angle, because the hydride ligand opposes a 
weaker repulsive effect relative to the $\mathrm{OH}$ and $\mathrm{H}_{2} \mathrm{O}$ ligands. The optimized ferrocene (eclipsed configuration) has distances $(\mathrm{Fe}-\mathrm{C} 2.120 \AA$, C-C $1.443 \AA$ ) in good agreement with those determined by $\mathrm{X}$-ray ${ }^{68}$ and neutron diffraction. ${ }^{69}$ The ferrocenium cation $(\mathrm{S}=1 / 2)$ gave a slightly distorted eclipsed geometry ( $13^{\circ}$ distortion, Fe-C $2.164 \AA$ A, C-C $1.443 \AA$ ) .

\section{Discussion}

As stated in the Introduction, the decomposition of $\mathbf{1}^{+}$in dry $\mathrm{MeCN}$ has been the subject of a recent report from our Laboratory. ${ }^{38}$ The new results reported herein show that water can participate in the decomposition scheme of oxidized hydride complexes by acting as a ligand and deviate the decomposition path toward the formation of higher oxidation state organometallic hydroxo and oxo derivatives.

\section{Water as a ligand and not as a base}

Water is not expected to act as a deprotonating agent toward $\mathbf{1}^{+}$in the presence of $\mathbf{1}$. This is because it has been shown previously that compound $\mathbf{1}$ can be protonated by strong acids in water ${ }^{41}$ (that is, $\mathbf{1}$ is a stronger base than water). As a matter of fact, compound $\mathbf{1}$ is even a stronger base than $\mathrm{PMe}_{3}$. In a control experiment, we have shown that the protonation of a 1 : 1 mixture of compounds 1 and $\mathrm{PMe}_{3}$ with a substoichiometric amount of $\mathrm{HBF}_{4}$ gives rise to the NMR resonances $\left({ }^{1} \mathrm{H}\right.$ and $\left.{ }^{31} \mathrm{P}\right)$ of complex $[1-\mathrm{H}]^{1}$, while those of free $\mathrm{PMe}_{3}$ remain unchanged. In addition, no evidence for the formation of $\mathrm{PHMe}_{3}{ }^{+}$was ever obtained during the oxidation studies of $\mathbf{1}$, while the formation of $[\mathbf{1}-\mathrm{H}]^{+}$has been verified by NMR spectroscopy.

The computational work on the $\mathrm{PH}_{3}$ model systems also indicates that the Mo complex is the better base: from the data in Table 6, we calculate that equation (4) is highly exothermic. The quantitative result of the energetic calculation should be taken cautiously, because the solvent might significantly alter the energetic situation relative to the gas phase calculation via solvation effects. The solvation energies on the two sides of the equation, especially those related to the cationic species, might not balance off exactly. In addition, the replacement of $\mathrm{PH}_{3}$ with $\mathrm{PMe}_{3}$ should render both the free phosphine and the neutral hydride complex more basic. The inductive effect of a single $\mathrm{H} / \mathrm{Me}$ replacement will influence the basicity of the $\mathrm{P}$ lone pair (only one bond away) in a stronger way relative to the Mo lone pair (two bonds away). However, the Mo hydride complex has $9 \mathrm{H} / \mathrm{Me}$ substitutions as opposed to only three for the free phosphine. Once again, these effects might not balance off completely. An additional, 
probably smaller effect, is related to entropy changes. Considerations such as these should be kept in mind also when analyzing the other computed reaction energies below.

$$
\begin{array}{r}
\mathrm{PH}_{4}{ }^{+}+\mathrm{CpMoH}\left(\mathrm{PH}_{3}\right)_{3} \rightarrow \mathrm{PH}_{3}+\left[\mathrm{CpMoH}_{2}\left(\mathrm{PH}_{3}\right)_{3}\right]^{+} \\
\Delta E=-66.8 \mathrm{kcal} \mathrm{mol}^{-1}
\end{array}
$$

On the basis of the above considerations, we conclude that the presence of water (and even $\mathrm{PMe}_{3}$ ) as a base is irrelevant when compound $\mathbf{1}$ is present (for instance when part of $\mathbf{1}$ is left unoxidized by use of a substoichiometric amount of ferrocenium). Therefore, the different outcome of the oxidation under wet conditions (formation of 2,3 and 4) relative to the oxidation in dry MeCN or THF may be attributed to the coordination of water in place of a solvent molecule and to the follow-up reactivity that results from this event.

The deliberate addition of water to a $\mathrm{MeCN}$ solution does not change the course of the oxidation reaction of compound $\mathbf{1}$ in a substantial way, relative to the reported procedure in the dry solvent. ${ }^{38}$ The major products of this reaction are the same ones obtained under dry conditions. However, the formation of some oxo complex $\left[\mathrm{CpMoO}\left(\mathrm{PMe}_{3}\right)_{2}\right]^{+}$and the water adduct $\left[\mathrm{CpMoH}\left(\mathrm{PMe}_{3}\right)_{3}\left(\mathrm{H}_{2} \mathrm{O}\right)\right]^{2+}$ indicates that water is able to compete with the $\mathrm{MeCN}$ coordination and partially deviate the course of the decomposition of the $\mathbf{1}^{+}$intermediate. In the less coordinating solvents THF or acetone, the coordination of water is seen to compete even more favorably with the solvent, although the acetone adduct $\left[\mathrm{CpMoH}\left(\mathrm{PMe}_{3}\right)_{3}\left(\mathrm{CD}_{3} \mathrm{COCD}_{3}\right)\right]^{2+}$ has also been spectroscopically observed. Exchange studies carried out in $\mathrm{CD}_{3} \mathrm{CN}$ show that the acetone adduct is more susceptible than the water adduct toward exchange of the solvent donor.

\section{Mechanistic proposal}

A possible mechanism for the formation of the observed products is shown in Scheme 3, where all boxed species have been observed spectroscopically or analyzed by single crystal X-ray diffraction. This mechanism is consistent with the basic understanding that we have gained for this system by the studies in dry acetonitrile, ${ }^{38}$ with other related previous observations, and with the results of our computational studies. As the computational work has been used as an energetic guide for the rationalization of mechanistic pathways that also involve a few unobserved intermediates, a number of control calculations were also carried out. The first one involves the oxidation reaction itself. Reaction (5), a model of the oxidation process of $\mathbf{1}$, is 
strongly exothermic. Equalizing the calculated energy difference with the free energy change (both PV and entropy contributions are probably negligible), we arrive at a calculated reduction potential of $21.15 \mathrm{~V}$ for complex $\mathrm{CpMoH}\left(\mathrm{PH}_{3}\right)_{3}$ relative to the ferrocene standard. This compares with the experimentally determined value of $21.46 \mathrm{~V}$ for compound $\mathbf{1}$. Given that the $\mathrm{PMe}_{3}$ should be a better donor than $\mathrm{PH}_{3}$ and should render the hydride complex easier to oxidize, we consider the agreement of our calculations with the experimental data as satisfactory.

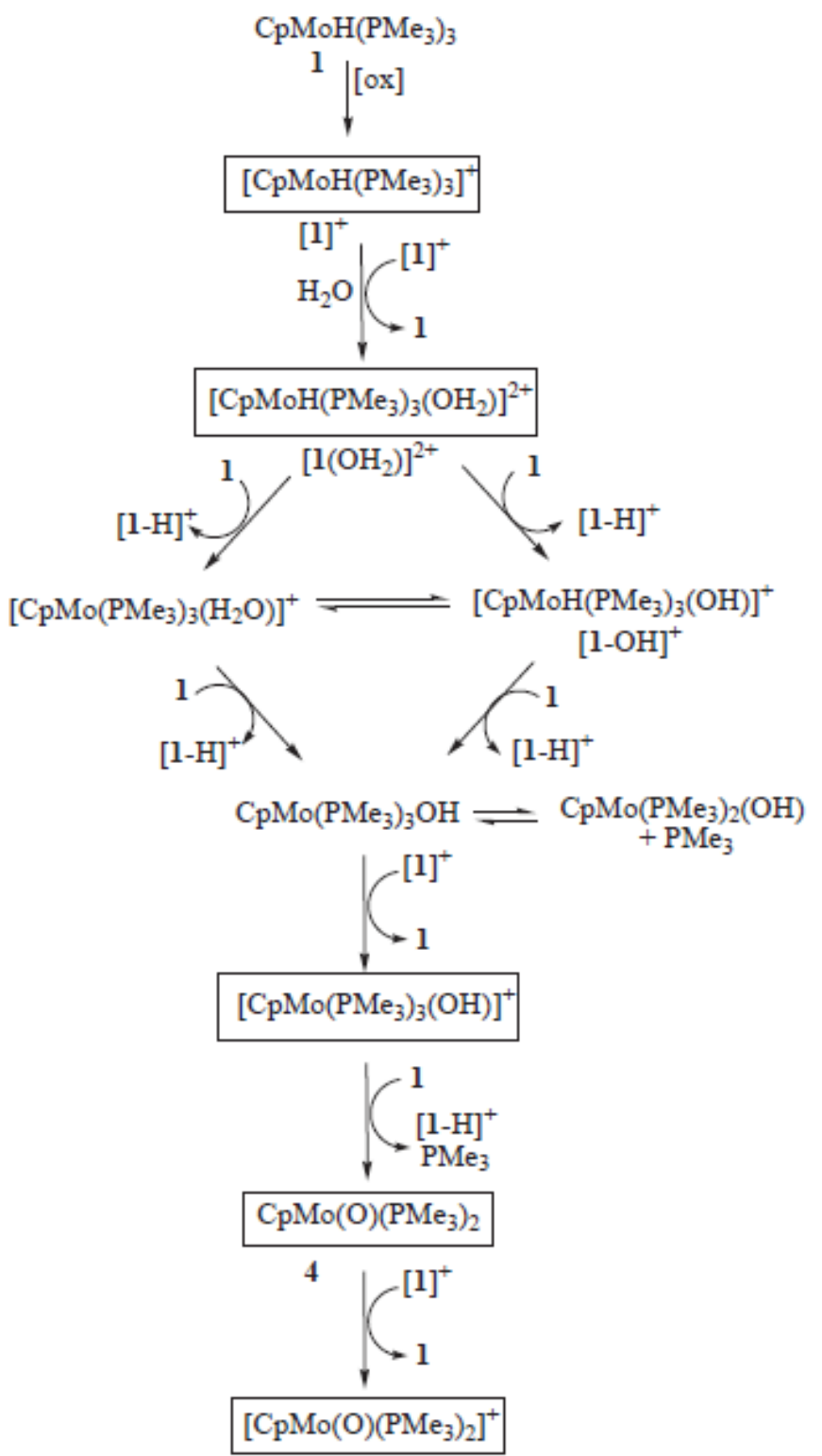

Scheme 3

$\mathrm{CpMoH}\left(\mathrm{PH}_{3}\right)_{3}+\mathrm{Fc}^{1} \rightarrow\left[\mathrm{CpMoH}\left(\mathrm{PH}_{3}\right)_{3}\right]^{+}+\mathrm{Fc}$ 


$$
\Delta E=-26.5 \mathrm{kcal} \mathrm{mol}^{-1}
$$

The mechanism in Scheme 3 parallels that established for $\mathbf{1}^{+}$in $\mathrm{MeCN}^{38}$ involving disproportionation of $\mathbf{1}^{+}$according to Scheme $2\left(\mathrm{~S}=\mathrm{H}_{2} \mathrm{O}\right)$. This involves the formation of $\left[\mathbf{1}\left(\mathrm{H}_{2} \mathrm{O}\right)\right]^{2+}$, analogous to the previously reported $[\mathbf{1}(\mathrm{THF})]^{2+}$ and $[\mathbf{1}(\mathrm{MeCN})]^{2+}, 38$ as an intermediate. NMR resonances that are attributed to complex $\left[1\left(\mathrm{H}_{2} \mathrm{O}\right)\right]^{2+}$ have been observed under particular conditions (see Results). There may be an equilibrium between the water adduct and other solvent adducts (e.g. $\left[1\left(\mathrm{CH}_{3} \mathrm{COCH}_{3}\right)\right]^{2+}$ in acetone), but only the former proceeds to further decomposition, as discussed below.

Water becomes more acidic when coordinated to a Lewis-acidic metal center. It is thus reasonable to suppose that the water ligand in the latter complex may be easily deprotonated, leading to complex $[\mathbf{1}-\mathrm{OH}]^{+}$, which is still an 18-electron complex of Mo(IV). Hydridohydroxo complexes analogous to $[\mathbf{1}-\mathrm{OH}]^{+}$are amply precedented in the literature, for instance $\mathrm{Cp}_{2}{ }_{2} \mathrm{~W}(\mathrm{OH}) \mathrm{H}^{70}$ and $\left[\mathrm{IrH}(\mathrm{OH})\left(\mathrm{PMe}_{3}\right)_{4}\right]^{+} .{ }^{71}$ In addition, Mo(IV) complexes that are isoelectronic with $[1-\mathrm{OH}]^{+}$such as $\mathrm{CpMoH}(\mathrm{OH})\left(\mathrm{C}_{6} \mathrm{D}_{5}\right)\left(\mathrm{PMe}_{3}\right)_{2}$ and $\mathrm{CpMoH}(\mathrm{OH})\left(\eta^{2}-\right.$ $\left.\mathrm{CH}_{2} \mathrm{PMe}_{2}\right)\left(\mathrm{PMe}_{3}\right)$ have been implicated as intermediates in $\mathrm{C}-\mathrm{H}$ activation processes. ${ }^{49}$ However, an alternative possibility involves deprotonation of $\left[1\left(\mathrm{H}_{2} \mathrm{O}\right)\right]^{2+}$ at the metal, to afford the tautomer complex $\left[\mathrm{CpMo}\left(\mathrm{PMe}_{3}\right)_{3}\left(\mathrm{H}_{2} \mathrm{O}\right)\right]^{+}$. This corresponds to the pathway established in dry $\mathrm{MeCN}$, transforming $[\mathbf{1}(\mathrm{MeCN})]^{2+}$ to the final product $\left[\mathrm{CpMo}\left(\mathrm{PMe}_{3}\right)_{3}(\mathrm{MeCN})\right]^{+}$. Either way, the deprotonating agent must be $\mathbf{1}$, which is generated locally and stoichiometrically by the preceding electron transfer step. Indeed, complex $[\mathbf{1}-\mathrm{H}]^{+}$is one of the observed products of the oxidation of $\mathbf{1}$ in wet acetone or THF.

The calculations on the $\mathrm{PH}_{3}$ model systems indicate that the Mo(II) aquo complex is 4.0 kcal $\mathrm{mol}^{-1}$ more stable than the Mo(IV) hydrido-hydroxo tautomer, implying a stronger thermodynamic acidity at the hydride position for $\left[\mathrm{CpMoH}\left(\mathrm{PH}_{3}\right)_{3}\left(\mathrm{H}_{2} \mathrm{O}\right)\right]^{2+}$. The tautomerization reaction corresponds to an oxidative addition/reductive elimination of the water $\mathrm{O}-\mathrm{H}$ bond and could well be a very rapid process. It is relevant to mention here that a fast $\mathrm{Mo}\left(\mathrm{H}_{2} \mathrm{O}\right) / \mathrm{MoH}(\mathrm{OH})$ tautomerization process has been invoked for a very similar $\mathrm{CpMoH}(\mathrm{OH})\left(\eta^{2}-\mathrm{CH}_{2} \mathrm{PMe}_{2}\right)\left(\mathrm{PMe}_{3}\right)$ system to rationalize the rapid H/D scrambling between the hydroxo and $\mathrm{PMe}_{3}$ positions in compound $\mathrm{CpMo}(\mathrm{OH})\left(\mathrm{PMe}_{3}\right)_{2}{ }^{49}$

The alternative proton transfer decomposition pathway, according to the well established mechanism, ${ }^{16,18,19,26}$ would lead to the same product, viz. $\left[\mathrm{CpMo}\left(\mathrm{PMe}_{3}\right)_{3}\left(\mathrm{H}_{2} \mathrm{O}\right)\right]^{+}$or to the hydrido-hydroxo tautomer, according to Scheme 1. Up to this point, the oxidation of 1 with 1 equivalent of $\mathrm{Fc}^{+}$should proceed according to the stoichiometry of equation (6), which 
corresponds to that established for the decomposition of the $\mathbf{1}^{+}$radical in dry MeCN. However, there is no evidence in the NMR monitoring for the accumulation of an intermediate that could be interpreted as $\left[\mathrm{CpMo}\left(\mathrm{PMe}_{3}\right)_{3}\left(\mathrm{H}_{2} \mathrm{O}\right)\right]^{+}$. Therefore, if this intermediate forms, it must be further transformed rapidly under the reaction conditions.

$21-2 \mathrm{e}^{-}+\mathrm{H}_{2} \mathrm{O} \rightarrow[\mathbf{1}-\mathrm{H}]^{+}+\left[\mathrm{CpMo}\left(\mathrm{PMe}_{3}\right)_{3}\left(\mathrm{H}_{2} \mathrm{O}\right)\right]^{+}$

The transformation of $\left[\mathrm{CpMo}\left(\mathrm{PMe}_{3}\right)_{3}\left(\mathrm{H}_{2} \mathrm{O}\right)\right]^{+}$to the cation of 2 requires loss of one proton and one electron. The order of these events shown in Scheme 3 is suggested by the existence of $\mathrm{CpMo}(\mathrm{OH})\left(\mathrm{PMe}_{3}\right)_{2},{ }^{39,49}$ and by the energetics of Table $6 . \mathrm{CpMo}(\mathrm{OH})\left(\mathrm{PMe}_{3}\right)_{3}$ is unstable relative to $\mathrm{PMe}_{3}$ dissociation and formation of the 16-electron $\mathrm{CpMo}(\mathrm{OH})\left(\mathrm{PMe}_{3}\right)_{2}$ complex, a spin triplet complex. ${ }^{49}$ The deprotonation process [equation (7)] is predicted as too unfavorable when using $\mathrm{PMe}_{3}$ or $\mathrm{H}_{2} \mathrm{O}$ as a base. Thus, this pathway is possible only in the presence of unoxidized 1.

$$
\begin{aligned}
{\left[\mathrm{CpMo}\left(\mathrm{PH}_{3}\right)_{3}\left(\mathrm{H}_{2} \mathrm{O}\right)\right]^{+}+\mathrm{CpMoH}\left(\mathrm{PH}_{3}\right)_{3} } & \rightarrow \mathrm{CpMo}(\mathrm{OH})\left(\mathrm{PH}_{3}\right)_{3}+\left[\mathrm{CpMoH}_{2}\left(\mathrm{PH}_{3}\right)_{3}\right]^{+} \\
\Delta E & =+1.8 \mathrm{kcal} \mathrm{mol}^{-1}
\end{aligned}
$$

Complex $\mathrm{CpMo}(\mathrm{OH})\left(\mathrm{PMe}_{3}\right)_{2}$ is not spectroscopically observed during the oxidation of $\mathbf{1}$, thus electron transfer must rapidly follow the proton loss. It is also worth noting here that, as we have previously shown, ${ }^{39,49}$ the $\mathrm{FcBF}_{4}$ oxidation of isolated $\mathrm{CpMo}(\mathrm{OH})\left(\mathrm{PMe}_{3}\right)_{2}$ in the presence of $\mathrm{PMe}_{3}$ affords a mixture of 2 and 3. The oxidation of $\mathrm{CpMo}(\mathrm{OH})\left(\mathrm{PMe}_{3}\right)_{3}$ (in equilibrium with $\mathrm{CpMo}(\mathrm{OH})\left(\mathrm{PMe}_{3}\right)_{2}$ and free $\left.\mathrm{PMe}_{3}\right)$ may be accomplished again by the longlived $\mathbf{1}^{+}$radical as indicated in Scheme 3. The model $\mathrm{PH}_{3}$ system confirms the feasibility of this electron transfer process [equation (8)].

$$
\begin{gathered}
\mathrm{CpMo}(\mathrm{OH})\left(\mathrm{PH}_{3}\right)_{3}+\left[\mathrm{CpMoH}\left(\mathrm{PH}_{3}\right)_{3}\right]^{+} \rightarrow\left[\mathrm{CpMo}(\mathrm{OH})\left(\mathrm{PH}_{3}\right)_{3}\right]^{+}+\mathrm{CpMoH}\left(\mathrm{PH}_{3}\right)_{3} \\
\Delta E=-5.5 \mathrm{kcal} \mathrm{mol}^{-1}
\end{gathered}
$$

The formation of $\mathbf{2}$ from 1 requires the consumption of 3 oxidizing equivalents and leads to the release of 2 equivalents of protons. The resulting stoichiometry is that of equation (9). Note that this equation involves an ox/1 ratio of $1: 1$, just like equation (6).

$$
31-3 \mathrm{e}^{-}+\mathrm{H}_{2} \mathrm{O} \rightarrow 2[1-\mathrm{H}]^{+}+\left[\mathrm{CpMo}(\mathrm{OH})\left(\mathrm{PMe}_{3}\right)_{3}\right]^{+}
$$


Compound $\mathbf{3}$ is obtained by further oxidation of $\mathbf{2}$, probably via deprotonation and loss of $\mathrm{PMe}_{3}$ to afford the neutral $\mathrm{Mo}(\mathrm{III})$ oxo intermediate $\mathrm{CpMo}(\mathrm{O})\left(\mathrm{PMe}_{3}\right)_{2}$, 4, which can subsequently be oxidized to $\mathbf{3}$. The formation of $\mathbf{4}$ and $\mathbf{3}$ requires the stoichiometries of equations (10) and (11), respectively. Equation (11) involves again an ox/1 ratio of $1: 1$, whereas the formation of $\mathbf{4}$ in equation (10) requires less than 1 equivalent of oxidant.

$$
\begin{aligned}
& 41-3 \mathrm{e}^{-}+\mathrm{H}_{2} \mathrm{O} \rightarrow 3[1-\mathrm{H}]^{+}+\mathbf{4}+\mathrm{PMe}_{3} \\
& 41-4 \mathrm{e}^{-}+\mathrm{H}_{2} \mathrm{O} \rightarrow 3[1-\mathrm{H}]^{+}+\left[\mathrm{CpMoO}\left(\mathrm{PMe}_{3}\right)_{2}\right]^{+}+\mathrm{PMe}_{3}
\end{aligned}
$$

The observation of the EPR triplet resonance when using a small amount of oxidant (see Fig. 1), is in agreement with the above argument. No other species involved in Scheme 3 could give rise to the observed EPR resonance. Our attempts to optimize a neutral $\mathrm{CpMoO}\left(\mathrm{PH}_{3}\right)_{3}$ model led to direct expulsion of a $\mathrm{PH}_{3}$ ligand and converged to two separate $\mathrm{CpMoO}\left(\mathrm{PH}_{3}\right)_{2}$ and $\mathrm{PH}_{3}$ units. The experimental evidence of a fast exchange between free $\mathrm{PMe}_{3}$ and the ligand coordinated to compound 4 (see Results) indicates, however, that a $\mathrm{CpMoO}\left(\mathrm{PMe}_{3}\right)_{3}$ complex may be easily accessible as a transient. The thermodynamic feasibility of the overall deprotonation process is shown in equation (12). Although the process is calculated as slightly endothermic, the reaction is entropically favored by the release of one molecule of free $\mathrm{PH}_{3} . \mathrm{A}$ spontaneous deprotonation of $\left[\mathrm{CpMo}(\mathrm{OH})\left(\mathrm{PMe}_{3}\right)_{3}\right]^{+}$with proton capture by the released $\mathrm{PMe}_{3}$ ligand does not seem consistent with the calculations on the model system [equation (13)]. The subsequent oxidation of $\mathbf{4}$ by $\mathbf{1}^{+}$is also a favorable process, as indicated in the model system by equation (14).

$$
\begin{gathered}
{\left[\mathrm{CpMo}(\mathrm{OH})\left(\mathrm{PH}_{3}\right)_{3}\right]^{+}+\mathrm{CpMoH}\left(\mathrm{PH}_{3}\right)_{3} \rightarrow\left[\mathrm{CpMoH}_{2}\left(\mathrm{PH}_{3}\right)_{3}\right]^{+}+\mathrm{CpMoO}\left(\mathrm{PH}_{3}\right)_{2}+\mathrm{PH}_{3}} \\
\Delta E=+4.7 \mathrm{kcal} \mathrm{mol}^{-1} \\
{\left[\mathrm{CpMo}(\mathrm{OH})\left(\mathrm{PH}_{3}\right)_{3}\right]^{1} \rightarrow \mathrm{CpMoO}\left(\mathrm{PH}_{3}\right)_{2}+\mathrm{PH}_{4}^{+}} \\
\Delta E=+71.7 \mathrm{kcal} \mathrm{mol}^{-1} \\
\mathrm{CpMoO}\left(\mathrm{PH}_{3}\right)_{2}+\left[\mathrm{CpMoH}\left(\mathrm{PH}_{3}\right)_{3}\right]^{+} \rightarrow\left[\mathrm{CpMoO}\left(\mathrm{PH}_{3}\right)_{2}\right]^{+}+\mathrm{CpMoH}\left(\mathrm{PH}_{3}\right)_{3} \\
\Delta E
\end{gathered}
$$

It is interesting to observe that each oxidation step is followed by the release of a proton, and that each molecule of the oxidizing $\mathbf{1}^{+}$generates a molecule of 1 that can capture the proton. Thus, all $\mathbf{1}$ is ultimately consumed by the oxidation reaction with 1 equivalent of ferrocenium, 
to yield the oxidation products and the protonation product $[1-\mathrm{H}]^{+}$. According to the stoichiometry of equations (9), (10) and (11), compound 4 should only be observed when using a substoichiometric amount of oxidant (experimentally verified), while the use of 1 or more equivalents of oxidant should yield only $\mathbf{2}$ and $\mathbf{3}$.

In conclusion, the formation of oxo and hydroxo products probably starts with coordination of a water molecule to an unsaturated metal center which is generated by an oxidation process, and continues with tandem oxidation/deprotonation steps.

\section{Conclusions}

With this contribution we have shown that water can intervene in the decomposition of paramagnetic hydride complexes not only as a proton acceptor, as previously established for less electron-rich hydride complexes, but also as a ligand. This event leads to higher oxidation state hydroxo and oxo complexes via a cascade of energetically favorable deprotonation/oxidation steps. The existence of sequential electron and proton transfer reactions is well documented in coordination chemistry. In particular, these tandem reactions on molybdenum derivatives containing a coordinated water residue have been proven biologically relevant. ${ }^{72,73}$ When the parent neutral hydride is loaded with electron-releasing ligands, it becomes more basic than water and is the preferred proton acceptor. However, the need for a donor solvent to electronically saturate the products of decomposition of the paramagnetic hydride may make water the preferred substrate when this process is carried out in solvents of limited coordinating ability. The follow-up processes are then a consequence of the increased acidity of water upon coordination to the Lewis-acidic metal center.

\section{Acknowledgments}

We are grateful to the DOE (grant no. DEFG059ER14230) for support of this work and to Dr Raymund C. Torralba for some preliminary observations.

\section{References}

$1 \quad$ J. R. Sanders, J. Chem. Soc., Dalton Trans., 1973, 748.

$2 \quad$ J. R. Sanders, J. Chem. Soc., Dalton Trans., 1975, 2340. 
3 M. Gargano, P. Giannoccaro, M. Rossi, G. Vasapollo and A. Sacco, J. Chem. Soc., Dalton Trans., 1975, 9.

4 G. Pilloni, G. Schiavon, G. Zotti and S. Zecchin, J. Organomet. Chem., 1977, 134, 305.

5 P. M. Treichel, D. C. Molzahn and K. P. Wagner, J. Organomet. Chem., 1979, 174, 191.

6 R. J. Klinger, J. C. Huffman and J. K. Kochi, J. Am. Chem. Soc., 1980, 102, 208.

7 J. D. Allison, C. J. Cameron, R. E. Wild and R. A. Walton, J. Organomet. Chem., 1981, 218, C62.

8 L. F. Rhodes, J. D. Zubkowski, K. Folting, J. C. Huffman and K. G. Caulton, Inorg. Chem., 1982, 21, 4185.

9 J. W. Bruno and K. G. Caulton, J. Organomet. Chem., 1986, 315, C13.

10 M. R. Detty and W. D. Jones, J. Am. Chem. Soc., 1987, 109, 5666.

11 M. T. Costello and R. A. Walton, Inorg. Chem., 1988, 27, 2563.

12 W. A. Herrmann, H. G. Theiler, E. Herdtweck and P. Kiprof, J. Organomet. Chem., 1989, 367, 291.

13 C. Bianchini, F. Laschi, M. Peruzzini, F. Ottaviani, A. Vacca and P. Zanello, Inorg. Chem., 1990, 29, 3394.

14 L. Chen and J. A. Davies, Inorg. Chim. Acta, 1990, 175, 41.

15 L. Roullier, D. Lucas, Y. Mugnier, A. Antiñolo, M. Fajardo and A. Otero, J. Organomet. Chem., 1990, 396, C12.

16 O. B. Ryan, M. Tilset and V. D. Parker, J. Am. Chem. Soc., 1990, 112, 2618.

17 O. B. Ryan, K.-T. Smith and M. Tilset, J. Organomet. Chem., 1991, 421, 315.

18 O. B. Ryan, M. Tilset and V. D. Parker, Organometallics, 1991, 10, 298.

19 O. B. Ryan and M. Tilset, J. Am. Chem. Soc., 1991, 113, 9554.

20 C. Roger, P. Hamon, L. Toupet, H. Rabaâ, J.-Y. Saillard, J.-R. Hamon and C. Lapinte, Organometallics, 1991, 10, 1045.

21 L. Roullier, D. Lucas, Y. Mugnier, A. Antiñolo, M. Fajardo and A. Otero, J. Organomet. Chem., 1991, 412, 353. 
22 D. E. Westerberg, L. F. Rhodes, J. Edwin, W. E. Geiger and K. G. Caulton, Inorg. Chem., 1991, 30, 1107.

23 P. Hamon, L. Toupet, J.-R. Hamon and C. Lapinte, Organometallics, 1992, 11, 1429.

24 M. Tilset, J. Am. Chem. Soc., 1992, 114, 2740.

25 G. Jia, A. J. Lough and R. H. Morris, Organometallics, 1992, 11, 161.

26 K.-T. Smith and M. Tilset, J. Organomet. Chem., 1992, 431, 55.

27 C. Amatore, J. J. R. Fraústo da Silva, M. F. C. Guedes da Silva, A. J. L. Pombeiro and J.N. Verpeaux, J. Chem. Soc., Chem. Commun., 1992, 1289.

28 V. Skagestad and M. Tilset, J. Am. Chem. Soc., 1993, 115, 5077.

29 A. A. Zlota, M. Tilset and K. G. Caulton, Inorg. Chem., 1993, 32, 3816.

30 K.-T. Smith, C. Rømming and M. Tilset, J. Am. Chem. Soc., 1993, 115, 8681.

31 M. Jiménez-Tenorio, M. C. Puerta and P. Valerga, Organometallics, 1994, 13, 3330.

32 W. Kaim, R. Reinhardt and M. Sieger, Inorg. Chem., 1994, 33, 4453.

33 A. Pedersen and M. Tilset, Organometallics, 1994, 13, 4887.

34 C. A. Blaine, J. E. Ellis and K. R. Mann, Inorg. Chem., 1995, 34, 1552.

35 R. T. Hembre, J. S. McQueen and V. W. Day, J. Am. Chem. Soc., 1996, 118, 798.

36 D. Menglet, A. M. Bond, K. Coutinho, R. S. Dickson, G. G. Lazarev, S. A. Olsen and J. R. Pilbrow, J. Am. Chem. Soc., 1998, 120, 2086.

37 E. A. Quadrelli, H.-B. Kraatz and R. Poli, Inorg. Chem., 1996, 35, 5154.

38 J. C. Fettinger, H.-B. Kraatz, R. Poli, E. A. Quadrelli and R. C. Torralba, Organometallics, 1998, 17, 5767.

39 J. C. Fettinger, H.-B. Kraatz, R. Poli and E. A. Quadrelli, Chem. Commun., 1997, 889.

40 F. Abugideiri, M. A. Kelland, R. Poli and A. L. Rheingold, Organometallics, 1992, 11, 1303.

41 M. Brookhart, K. Cox, F. G. N. Cloke, J. C. Green, M. L. H. Green, P. M. Hare, J. Bashkin, A. E. Derome and P. D. Grebenik, J. Chem. Soc., Dalton Trans., 1985, 423. 
42 M. J. Frisch, G. W. Trucks, H. B. Schlegel, P. M. W. Gill, B. G. Johnson, M. A. Robb, J. R. Cheeseman, T. A. Keith, G. A. Petersson, J. A. Montgomery, K. Raghavachari, M. A. Al-Laham, V. G. Zakrzewski, J. V. Ortiz, J. B. Foresman, J. Cioslowski, B. B. Stefanov, A. Nanayakkara, M. Challacombe, C. Y. Peng, P. Y. Ayala, W. Chen, M. W. Wong, J. L. Andres, E. S. Replogle, R. Gomperts, R. L. Martin, D. J. Fox, J. S. Binkley, D. J. Defrees, J. Baker, J. P. Stewart, M. Head-Gordon, C. Gonzales and J. A. Pople, Gaussian 94 (Revision E.1). Gaussian Inc., Pittsburgh, PA, 1995.

43 A. D. Becke, J. Chem. Phys., 1993, 98, 5648.

44 T. H. Dunning, Jr. and P. J. Hay, in Modern Theoretical Chemistry ed. H. F. Schaefer, III, Plenum Press, New York, 1976, p. 1.

45 P. J. Hay and W. R. Wadt, J. Chem. Phys., 1985, 82, 270.

46 P. J. Hay and W. R. Wadt, J. Chem. Phys., 1985, 82, 299.

47 W. R. Wadt and P. J. Hay, J. Chem. Phys., 1985, 82, 284.

48 J. C. Fettinger, H.-B. Kraatz, R. Poli and A. L. Rheingold, Acta Crystallogr., Sect. C, 1995, 51, 364.

49 R. Poli and E. A. Quadrelli, New J. Chem., 1998, 22, 435.

50 G. S. B. Adams and M. L. H. Green, J. Chem. Soc., Dalton Trans., 1981, 353.

51 B. Antelmann, G. Huttner and U. Winterhalter, J. Organomet. Chem., 1998, 555, 119.

52 G. G. Kneale, A. J. Geddes, Y. Sasaki, T. Shibahara and A. G. Sykes, J. Chem. Soc., Chem. Commun., 1975, 356.

53 K. Wieghardt, M. Hahn, W. Swiridoff and J. Weiss, Inorg. Chem., 1984, 23, 94.

54 P. Chauduri, K. Wieghardt, I. Jibril and G. Huttner, Z. Naturforsch., Teil B, 1984, 39, 1172 .

55 R. Poli, Organometallics, 1990, 9, 1892.

56 Z. Lin and M. B. Hall, Organometallics, 1993, 12, 19.

57 B. E. Owens and R. Poli, Acta Crystallogr., Sect. C, 1992, 48, 2137.

58 L. Manojlovic-Muir, J. Chem. Soc., Dalton Trans., 1971, 2796. 
59 L. Manojlovic-Muir and K. W. Muir, J. Chem. Soc., Dalton Trans., 1972, 686.

60 J. Bendix, H. Birkedal and A. Bøgevig, Inorg. Chem., 1997, 36, 2702.

61 G. Parkin, Acc. Chem. Res., 1992, 25, 455.

62 W. A. Herrmann, E. Herdtweck, M. Flöel, J. Kulpe, U. Küsthardt and J. Okuda, Polyhedron, 1987, 6, 1165.

63 I. Cacelli, D. W. Keogh, R. Poli and A. Rizzo, New J. Chem., 1997, 21, 133.

64 Recent developments and Applications of Modern density Functional Theory, ed. J. M. Seminario, Elsevier, Amsterdam, 1996.

65 F. Abugideiri, J. C. Fettinger, B. Pleune, R. Poli, C. A. Bayse and M. B. Hall, Organometallics, 1997, 16, 1179.

66 M. L. H. Green, A. K. Hughes, P. Lincoln, J. J. Martin-Polo, P. Mountford, A. Sella, L.L. Wong, J. A. Bandy, T. W. Banks, K. Prout and D. J. Watkin, J. Chem. Soc., Dalton Trans., 1992, 2063.

67 B. Pleune, D. Morales, R. Meunier-Prest, P. Richard, E. Collange, J. C. Fettinger and R. Poli, J. Am. Chem. Soc., submitted.

68 P. Seiler and J. D. Dunitz, Acta Crystallogr., Sect. B, 1979, 35, 1068.

69 F. Takusagawa and T. F. Koetzle, Acta Crystallogr., Sect. B, 1979, 35, 1074.

70 G. Parkin and J. E. Bercaw, Organometallics, 1989, 8, 1172.

71 D. Milstein, J. C. Calabrese and I. D. Williams, J. Am. Chem. Soc., 1986, 108, 6387.

72 E. I. Stiefel, Proc. Natl. Acad. Sci. USA, 1973, 70, 988.

73 E. I. Stiefel, J. Chem. Soc., Dalton Trans., 1997, 3915. 